\title{
Overview of aerosol optical properties over southern West Africa from DACCIWA aircraft measurements
}

\author{
Cyrielle Denjean $^{1}$, Thierry Bourrianne ${ }^{1}$, Frederic Burnet $^{1}$, Marc Mallet $^{1}$, Nicolas Maury ${ }^{1}$, Aurélie Colomb $^{2}$, \\ Pamela Dominutti $^{2, a}$, Joel Brito ${ }^{2, b}$, Régis Dupuy ${ }^{2}$, Karine Sellegri $^{2}$, Alfons Schwarzenboeck ${ }^{2}$, Cyrille Flamant ${ }^{3}$, and \\ Peter Knippertz ${ }^{4}$ \\ ${ }^{1}$ CNRM, Université de Toulouse, Météo-France, CNRS, Toulouse, France \\ ${ }^{2}$ LaMP, Université de Clermont Auvergne, Clermont-Ferrand, France \\ ${ }^{3}$ LATMOS/IPSL, Sorbonne Université, UVSQ, CNRS, Paris, France \\ ${ }^{4}$ Institute of Meteorology and Climate Research, Karlsruhe Institute of Technology, Karlsruhe, Germany \\ ${ }^{a}$ now at: Wolfson Atmospheric Chemistry Laboratories, Department of Chemistry, University of York, YO10 5DD-York, UK \\ bnow at: IMT Lille Douai, Université de Lille, SAGE, Lille, France
}

Correspondence: Cyrielle Denjean (cyrielle.denjean@meteo.fr)

Received: 20 June 2019 - Discussion started: 9 August 2019

Revised: 4 March 2020 - Accepted: 12 March 2020 - Published: 22 April 2020

\begin{abstract}
Southern West Africa (SWA) is an African pollution hotspot but a relatively poorly sampled region of the world. We present an overview of in situ aerosol optical measurements collected over SWA in June and July 2016 as part as of the DACCIWA (Dynamics-Aerosol-Chemistry-Clouds Interactions in West Africa) airborne campaign. The aircraft sampled a wide range of air masses, including anthropogenic pollution plumes emitted from the coastal cities, long-range transported biomass burning plumes from central and southern Africa and dust plumes from the Sahara and Sahel region, as well as mixtures of these plumes. The specific objective of this work is to characterize the regional variability of the vertical distribution of aerosol particles and their spectral optical properties (single scattering albedo: SSA, asymmetry parameter, extinction mass efficiency, scattering Ångström exponent and absorption Ångström exponent: AAE). The first findings indicate that aerosol optical properties in the planetary boundary layer were dominated by a widespread and persistent biomass burning loading from the Southern Hemisphere. Despite a strong increase in aerosol number concentration in air masses downwind of urban conglomerations, spectral SSA were comparable to the background and showed signatures of the absorption characteristics of biomass burning aerosols. In the free troposphere, moderately to strongly absorbing aerosol layers, dominated by either dust or biomass burning particles, occurred occasionally.
\end{abstract}

In aerosol layers dominated by mineral dust particles, SSA varied from 0.81 to 0.92 at $550 \mathrm{~nm}$ depending on the variable proportion of anthropogenic pollution particles externally mixed with the dust. For the layers dominated by biomass burning particles, aerosol particles were significantly more light absorbing than those previously measured in other areas (e.g. Amazonia, North America), with SSA ranging from 0.71 to 0.77 at $550 \mathrm{~nm}$. The variability of SSA was mainly controlled by variations in aerosol composition rather than in aerosol size distribution. Correspondingly, values of AAE ranged from 0.9 to 1.1 , suggesting that lens-coated black carbon particles were the dominant absorber in the visible range for these biomass burning aerosols. Comparison with the literature shows a consistent picture of increasing absorption enhancement of biomass burning aerosol from emission to remote location and underscores that the evolution of SSA occurred a long time after emission.

The results presented here build a fundamental basis of knowledge about the aerosol optical properties observed over SWA during the monsoon season and can be used in climate modelling studies and satellite retrievals. In particular and regarding the very high absorbing properties of biomass burning aerosols over SWA, our findings suggest that considering the effect of internal mixing on absorption properties of black carbon particles in climate models should help better assess 
the direct and semi-direct radiative effects of biomass burning particles.

\section{Introduction}

Atmospheric aerosols play a crucial role in the climate system by altering the radiation budget through scattering and absorption of solar radiation and by modifying cloud properties and lifetime. Yet considerable uncertainties remain about the contribution of both natural and anthropogenic aerosol to the overall radiative effect (Boucher et al., 2013). Large uncertainties are related to the complex and variable properties of aerosol particles that depend on the aerosol source and nature as well as on spatial and temporal variations. During transport in the atmosphere, aerosol particles may undergo physical and chemical aging processes altering the composition and size distribution and henceforth the optical properties and radiative effects. The capability of reproducing this variability in climate models represents a real challenge (Myhre et al., 2013; Stier et al., 2013; Mann et al., 2014). Therefore, intensive experimental observations in both aerosol source and remote areas are of paramount importance for constraining and evaluating climate models.

Key parameters from a climate perspective are the aerosol vertical distribution and respective spectral optical properties. Radiative transfer codes commonly incorporated in climate models and in satellite data retrieval algorithms use single scattering albedo (SSA), mass extinction efficiency (MEE) and asymmetry factor $(g)$ as input parameters. These parameters depend on the aerosol size distribution, the real and imaginary parts of the refractive index $(n-i k)$, and the wavelength of incident light, $\lambda$. The knowledge of the vertical distribution of these fundamental parameters is crucial to accurately estimate the direct and semi-direct radiative effects of aerosols as well as the vertical structure of atmospheric heating rates resulting from absorption by particles. The above information is also required to retrieve aerosol properties (aerosol optical depth, size distribution) from remote sensing data.

Southern West Africa (SWA) is one of the most climatevulnerable regions in the world, where the surface temperature is expected to increase by $\sim 3 \mathrm{~K}$ at the end of the century (2071-2100) in the Coupled Model Intercomparison Project Phase 5 (CMIP5) (Roehrig et al., 2013). It is characterized by a fast-growing population, industrialization and urbanization (Liousse et al., 2014). This is particularly the case along the Guinean coast, where several already large cities are experiencing rapid growth (Knippertz et al., 2015a). Despite these dramatic changes, poor regulation strategies of traffic, industrial and domestic emissions lead to a marked increase in anthropogenic aerosol loading from multiple sources, including road traffic, industrial activities, waste burning, ship plumes, domestic fires, and power plants. Tangible evidence of regional transport of anthropogenic pollutants associated with urban emissions has altered air pollution from a local issue to a regional issue and beyond (Deetz et al., 2018; Deroubaix et al., 2019). This is particularly the case during summer, when land-sea breeze systems can develop and promote the transport of pollutants inland, away from the urbanized coastal strip of SWA (Flamant et al., 2018a). In addition to this anthropogenic regional pollution, SWA is impacted by a significant import of aerosols from remote sources. Biomass burning mainly from vegetation fires in central Africa are advected to SWA in the marine boundary layer and aloft (Mari et al., 2008; Menut et al., 2018; Haslett et al., 2019). The nearby Sahara and the Sahel are large sources of natural wind-blown mineral dust aerosol throughout the year, with a peak in springtime (Marticorena and Bergametti, 1996). Biomass burning, dust and anthropogenic pollution aerosols can be mixed along their transport pathways (Flamant et al., 2018a; Deroubaix et al., 2019), resulting in complex interactions between physical and chemical processes and even meteorological feedbacks.

In West Africa, most of the aerosol-radiation interaction studies focused on optical properties of dust and biomass burning aerosols in remote regions far from major sources of anthropogenic pollution aerosol. They include ground-based and airborne field campaigns such as DABEX (Dust and Biomass Experiment; Haywood et al., 2008), AMMA (Analysis Multidisciplinary of African Monsoon; Lebel et al., 2010), DODO (Dust Outflow and Deposition to the Ocean; McConnell et al., 2008), SAMUM-1 and SAMUM-2 (Saharan Mineral Dust Experiment; Heintzenberg, 2009; Ansmann et al., 2011) and AER-D (AERosol Properties - Dust; Ryder et al., 2018). These projects concluded that the influence of both mineral dust and biomass burning aerosols on the radiation budget is significant over West Africa, implying that meteorological forecast and regional/global climate models should include their different radiative effects for accurate forecasts and climate simulations. Over the Sahel region, Solmon et al. (2008) have highlighted the high sensitivity of mineral dust optical properties to precipitation changes at a climatic scale. However, the optical properties of aerosol particles in the complex chemical environment of SWA are barely studied. This is partly due to the historically low level of industrial developments of the region. Motivated by the quickly growing cities along the Guinean coast, the study of transport, mixing, and feedback processes of aerosol particles is therefore very important for better quantification of aerosol radiative impact at the regional scale and improvement of climate and numerical weather prediction models.

In this context, the DACCIWA (Dynamics-AerosolChemistry-Clouds Interactions in West Africa; Knippertz et al., 2015b) campaign, designed to characterize both natural and anthropogenic emissions over SWA, provides important and unique observations of aerosols in a region much more affected by anthropogenic emissions than previously thought. A comprehensive field campaign took place in 
June-July 2016 including extensive ground-based (Kalthoff et al., 2018) and airborne measurements (Flamant et al., 2018b). In this study, we present an overview of in situ airborne measurements of the vertical distribution of aerosol particles and their spectral optical properties acquired with the ATR-42 French research aircraft over the Guinean coast.

Section 2 presents the flight patterns, instrumentation and data analysis. Section 3 provides an overview of the aerosol microphysical and optical properties. The impact of aging and mixing processes on aerosol optical properties is discussed in Sect. 4 before conclusions are presented in Sect. 5 .

\section{Methodology}

\subsection{ATR-42 measurement overview}

This analysis focuses on flight missions conducted by the ATR-42 aircraft of SAFIRE (Service des Avions Français Instrumentés pour la Recherche en Environnement - the French aircraft service for environmental research) over the Gulf of Guinea and inland. A full description of flight patterns during DACCIWA is given in Flamant et al. (2018b). Here we present results from 15 flights focused on the characterization of anthropogenic pollution, dust and biomass burning plumes. The flight tracks are shown in Fig. 1 and a summary of flight information is provided in Table A1 in the Appendix. The sampling strategy generally consisted of two parts: first, vertical soundings were performed from $60 \mathrm{~m}$ up to $8 \mathrm{~km}$ above mean sea level (a.m.s.l.) to observe and identify interesting aerosol layers. Subsequently, the identified aerosol layers were probed with the in situ instruments by straight levelled runs (SLRs) at fixed flight altitudes.

The ATR-42 aircraft was equipped with a wide variety of instrumentation performing gas and aerosol measurements. The measured meteorological parameters include temperature, dew point temperature, pressure, turbulence, relative humidity, as well as wind speed and direction. Gas-phase species were sampled through a rear-facing $1 / 4$ inch Teflon tube. Carbon monoxide (CO) was measured using ultraviolet and infrared analysers (PICARRO). The nitric oxide (NO) and nitrogen dioxide $\left(\mathrm{NO}_{2}\right)$ measurements were performed using an ozone chemiluminescence instrument (Thermo Environmental Instrument TEi42C with a Blue Light Converter for the $\mathrm{NO}_{2}$ conversion). On-board aerosol instruments sampled ambient air via stainless steel tubing through the Community Aerosol Inlet (CAI). This is an isokinetic and isoaxial inlet with a $50 \%$ sampling efficiency for particles with a diameter of $5 \mu \mathrm{m}$ (Denjean et al., 2016).

The total number concentration of particles larger than $10 \mathrm{~nm}\left(N_{\text {tot }}\right)$ was measured by a butanol-based conductive cooling type condensation particle counter (CPC, model MARIE built by the University of Mainz; Mertes et al., 1995; Russell et al., 1996; Wiedensohler et al., 1997). The aerosol size distribution was measured using an ultra-high-

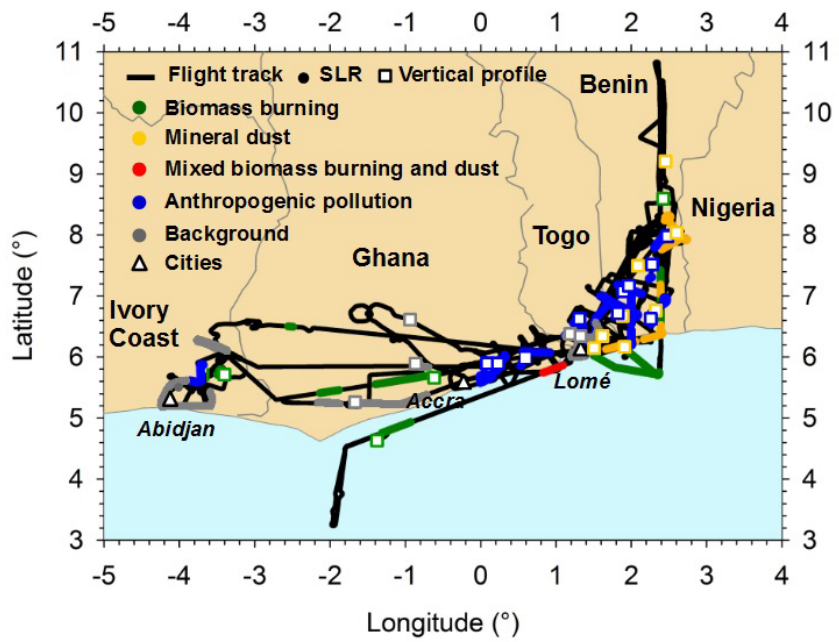

Figure 1. Tracks of the 15 flights analysed in this study. The colours indicate aircraft flight sampling layers dominated by biomass burning (green), mineral dust (orange), mixed dust-biomass burning (red), anthropogenic pollution (blue) and background particles (grey) from both vertical profiles (squares) and straight and level runs (SLRs; dots).

sensitivity aerosol spectrometer (UHSAS, DMT, 0.04-1 $\mu \mathrm{m}$ ), a custom-built scanning mobility sizer spectrometer (SMPS, 20-485 nm) and an optical particle counter (OPC, GRIMM model $1.109,0.3-32 \mu \mathrm{m})$. Instrument calibration was performed with PSL nanospheres and oil particles for diameters from $90 \mathrm{~nm}$ to $20 \mu \mathrm{m}$. The SMPS data acquisition system failed after two-thirds of the campaign and could not be repaired. We found the UHSAS to show false counts in the diameters below $100 \mathrm{~nm}$. Therefore, these channels were disregarded in the data analysis.

The particle extinction coefficient $\left(\sigma_{\text {ext }}\right)$ at the wavelength of $530 \mathrm{~nm}$ was measured with a cavity-attenuated phase shift particle light extinction monitor (CAPS-PMex, Aerodyne Research). The particle scattering coefficients $\left(\sigma_{\text {scat }}\right)$ at 450,550 and $635 \mathrm{~nm}$ were measured using a TSI 3563 3Wavelength Integrating Nephelometer and corrected for angular truncator error in the data inversion procedure using a Mie code (i.e. Sect. 2.3.1 and Fig. A1). The absorption coefficients $\left(\sigma_{\text {abs }}\right)$ at 467,520 and $660 \mathrm{~nm}$ were measured by a Radiance Research Particle Soot Absorption Photometer (PSAP). The PSAP measures changes in filter attenuation due to the collection of aerosol deposited on the filter, which were corrected for the scattering artifacts according to the Virkkula (2010) method. Prior to the campaign, the CAPS-PMex was evaluated against the combination of the integrating nephelometer and the PSAP. An instrument intercomparison was performed with purely scattering ammonium sulfate particles and with strongly absorbing black carbon (BC) particles. Both types of aerosol were generated by nebulizing a solution of the respective substances and sizeselected using a DMA. For instrument intercomparison pur- 
poses, $\sigma_{\text {ext }}$ from the combination of integrating nephelometer and PSAP was adjusted to that for $530 \mathrm{~nm}$ by using the scattering and absorption Ångstrom exponents (SAE and AAE, respectively). The instrument evaluation showed an excellent accuracy of the CAPS-PMex measurements by comparison to the integrating nephelometer and PSAP combination. The results were within the $\pm 3 \%$ uncertainty reported by Massoli et al. (2010) and Petzold et al. (2013) for the same instrument configuration.

\subsection{Ancillary products}

In order to determine the history of air masses prior to aircraft sampling, backward trajectories and satellite images were used. The trajectories were computed using the Hybrid Single Particle Lagrangian Integrated Trajectory Model (HYSPLIT) and the National Centers for Environmental Prediction (NCEP) Global Data Assimilation System (GDAS) data with $0.5^{\circ}$ horizontal resolution for sequences and times of interest. We compared the backward trajectory heights with information of fire burning times (e.g. MODIS Burnt Area Product) and dust release periods (e.g. Meteosat Second Generation (MSG) dust RGB composite images) to assess the aerosol source regions of the investigated air masses. The air masses represented by the trajectory are assumed to obtain their aerosol loading from source regions when the trajectory passes over regions with significant dust activation and/or fire activity at an altitude close to the surface. Trajectory calculations with slightly modified initial conditions with respect to the arrival time, location and altitude were performed to check the reliability of the location of source regions. Uncertainties in this approach, caused by unresolved vertical mixing processes and by general uncertainties of the trajectory calculations, are estimated to be in the range of 15\%-20\% of the trajectory distance (Stohl et al., 2002).

\subsection{Data analysis}

In the following, extensive aerosol parameters (concentrations, scattering, absorption and extinction coefficients) are converted to standard temperature and pressure (STP) using $T=273 \mathrm{~K}$ and $P=1013.25 \mathrm{hPa}$. The STP concentration data correspond to mixing ratios, which are independent of ambient pressure and temperature during the measurement. In the analysis, the data were averaged over sections of SLR with homogeneous aerosol conditions outside of clouds.

\subsubsection{Derivation of aerosol microphysical and optical properties}

Figure A1 and Table 1 show the iterative procedure and the equations used to calculate the aerosol microphysical and optical parameters as briefly explained below.

The particle number concentration in the coarse mode $\left(N_{\text {coarse }}\right)$ was calculated by integrating the OPC size distributions over the range 1 to $5 \mu \mathrm{m}$. The signal-to-noise ratio of the OPC for particles in this size range was higher than 3 , which makes the instrument well suited to quantifying variations in $N_{\text {coarse }}$. The number concentration of particles in the fine mode $\left(N_{\text {fine }}\right)$ was obtained as the difference between total number concentration $\left(N_{\text {tot }}\right.$ particle diameter range above $5 \mathrm{~nm}$ ) measured by the CPC and $N_{\text {coarse }}$.

For optical calculations, the $3 \lambda-\sigma_{\text {abs }}$ from the PSAP were adjusted at the three wavelengths measured by the integrating nephelometer using the AAE calculated from the $3 \lambda$ measured $\sigma_{\text {abs }}$. Once $\sigma_{\text {scat }}$ and $\sigma_{\text {abs }}$ were obtained at the same wavelength, an optical closure study estimated the complex refractive index based on optical and size data. Optical calculations were performed using Mie theory, implying a sphericity assumption, because it facilitates a quantitative comparison with past data, mostly using this simplification and because most climate models assume spherical properties. The retrieval algorithm consists of iteratively varying the real part of the complex refractive index $(n)$ from 1.33 to 1.60 and the imaginary part of the complex refractive index $(k)$ from 0.000 to 0.080 in steps of resolution of 0.001 . $n$ and $k$ were fixed when the difference between calculated values of $\sigma_{\text {scat }}$ and $\sigma_{\mathrm{abs}}$ and measurements was below $1 \%$. Given that the size distribution measured by the UHSAS and the OPC depends on $m$, the optical-to-geometrical diameter conversion was recalculated at each iteration based on the assumed $m$. The resulting number size distributions from SMPS, UHSAS and OPC were parameterized by fitting four log-normal distributions and used as input values in the optical calculations. Once $n$ and $k$ were obtained at $3 \lambda$, we estimated the following optical parameters.

- SAE depends on the size of the particles. Generally, it is lower than 0 for aerosols dominated by coarse particles, such as dust aerosols, but it is higher than 0 for fine particles, such as anthropogenic pollution or biomass burning aerosol (Seinfeld and Pandis, 2006; Schuster et al., 2006).

- AAE provides information about the chemical composition of atmospheric aerosols. BC absorbs radiation across the whole solar spectrum with the same efficiency; thus, it is characterized by AAE values around 1. Conversely, mineral dust particles show strong light absorption in the blue to ultraviolet spectrum, leading to AAE values up to 3 (Kirchstetter et al., 2004; Petzold et al., 2009).

- SSA describes the relative importance of scattering and absorption for radiation. Thus, it indicates the potential of aerosols to cool or warm the lower troposphere.

- $g$ describes the probability of radiation being scattered in a given direction. Values of $g$ can range from -1 for entirely backscattered light to +1 for complete forward scattering light. 
Table 1. Aerosol microphysical and optical properties derived in this work.

\begin{tabular}{|c|c|c|c|}
\hline Aerosol parameters & Symbol & $\lambda(\mathrm{nm})$ & Method \\
\hline \multicolumn{4}{|c|}{ Aerosol microphysical properties } \\
\hline $\begin{array}{l}\text { Total number } \\
\text { concentration }\end{array}$ & $N_{\text {tot }}$ & - & Measured by a CPC in the particle diameter range above $5 \mathrm{~nm}$ \\
\hline $\begin{array}{l}\text { Number concentration } \\
\text { in the coarse mode }\end{array}$ & $N_{\text {coarse }}$ & - & GRIMM size distributions integrated on the range 1 to $5 \mu \mathrm{m}$. \\
\hline $\begin{array}{l}\text { Number concentration } \\
\text { in the fine mode }\end{array}$ & $N_{\text {fine }}$ & - & Difference $N_{\text {tot }}$ and $N_{\text {coarse }}$. \\
\hline $\begin{array}{l}\text { Number size } \\
\text { distribution }\end{array}$ & $\mathrm{d} N / \mathrm{d} \log D p$ & - & $\begin{array}{l}\mathrm{d} N / \mathrm{d} \log D p=\Sigma_{i=1}^{4}\left(N_{\mathrm{tot}, i} \exp \left(-\left(\log D_{p}-\log D_{p, g, i}\right)^{2} /\right.\right. \\
\left.\left.\left(2 \log \sigma_{i}\right)\right) /\left(\sqrt{ } 2 \log \sigma_{i}\right)\right) \\
\text { with } N_{\mathrm{tot}, i} \text { the integrated number concentration, } D_{p, g, i} \text { the } \\
\text { geometric median diameter and } \sigma_{i} \text { geometric standard deviation } \\
\text { for each mode } i\end{array}$ \\
\hline $\begin{array}{l}\text { Volume size } \\
\text { distribution }\end{array}$ & $\mathrm{d} V / \mathrm{d} \log D p$ & - & $\begin{array}{l}\mathrm{d} V / \mathrm{d} \log D p=\Sigma_{i=1}^{4}\left(N_{\mathrm{tot}, i} D_{p}^{3} \pi / 6 \exp \left(-\left(\log D_{p}-\log D_{p, g, i}\right)^{2} /\right.\right. \\
\left.\left.\left(2 \log \sigma_{i}\right)\right) /\left(\sqrt{ } 2 \log \sigma_{i}\right)\right)\end{array}$ \\
\hline \multicolumn{4}{|c|}{ Aerosol optical properties } \\
\hline Scattering coefficient & $\sigma_{\text {scat }}$ & $450,550,635$ & $\begin{array}{l}\text { Measured by the integrating nephelometer and corrected for } \\
\text { truncator error }\end{array}$ \\
\hline Absorption coefficient & $\sigma_{\mathrm{abs}}$ & $467,520,660$ & Measured by the PSAP and corrected for filter-based artefacts \\
\hline Extinction coefficient & $\sigma_{\mathrm{ext}}$ & 530 & Measured by the CAPS-PMex \\
\hline $\begin{array}{l}\text { Scattering Ångström } \\
\text { exponent }\end{array}$ & SAE & 450 to 700 & $\begin{array}{l}\text { Calculated from the integrating nephelometer measurements: } \\
\mathrm{SAE}=-\ln \left(\sigma_{\text {scat }}(450) / \sigma_{\text {scat }}(700)\right) / \ln (450 / 700)\end{array}$ \\
\hline $\begin{array}{l}\text { Absorption Ångström } \\
\text { exponent }\end{array}$ & AAE & 440 to 660 & $\begin{array}{l}\text { Calculated from the PSAP measurements: } \\
\mathrm{AAE}=-\ln \left(\sigma_{\mathrm{abs}}(467) / \sigma_{\mathrm{abs}}(660)\right) / \ln (467 / 660)\end{array}$ \\
\hline $\begin{array}{l}\text { Complex refractive } \\
\text { index }\end{array}$ & $n$ & $450,550,660$ & $\begin{array}{l}\text { Inversion closure study using Mie theory (Fig. A1) } \\
m(\lambda)=n(\lambda)-i k(\lambda)\end{array}$ \\
\hline $\begin{array}{l}\text { Single scattering } \\
\text { albedo }\end{array}$ & SSA & $450,550,660$ & $\begin{array}{l}\text { Inversion closure study using Mie theory (Fig. A1) } \\
\operatorname{SSA}(\lambda)=\sigma_{\text {scat }}(\lambda) / \sigma_{\text {ext }}(\lambda)\end{array}$ \\
\hline $\begin{array}{l}\text { Mass extinction } \\
\text { efficiency }\end{array}$ & MEE & $450,550,660$ & $\begin{array}{l}\text { Inversion closure study using Mie theory (Fig. A1) } \\
\operatorname{MEE}(\lambda)=\sigma_{\text {ext }}(\lambda) / C_{\mathrm{m}} \\
\text { with } C_{\mathrm{m}} \text { the aerosol mass concentration }\end{array}$ \\
\hline Asymmetry parameter & $g$ & $450,550,660$ & $\begin{array}{l}\text { Inversion closure study using Mie theory (Fig. A1) } \\
g(\lambda)=1 / 2 \int_{0}^{\pi} \cos (\Theta) \sin (\Theta) P(\Theta, \lambda) \mathrm{d}(\Theta) \\
\text { with } P(\Theta, \lambda) \text { the scattering phase function and } \Theta \text { the scattering } \\
\text { angle. }\end{array}$ \\
\hline
\end{tabular}

- MEE represents the total light extinction per unit mass concentration of aerosol. The estimates of MEE assume mass densities of $2.65 \mathrm{~g} \mathrm{~cm}^{3}$ for dust aerosol, $1.35 \mathrm{~g} \mathrm{~cm}^{3}$ for biomass burning aerosol, $1.7 \mathrm{~g} \mathrm{~cm}^{3}$ for anthropogenic aerosol and $1.49 \mathrm{~g} \mathrm{~cm}^{3}$ for background aerosol (Hess et al., 1998; Haywood et al., 2003a).

\subsubsection{Classification of aerosol plumes}

Data were screened in order to isolate plumes dominated by anthropogenic pollution from urban emissions, biomass burning and mineral dust particles, resulting in a total number of 19, 12 and 8 genuine plume interceptions, respectively, across the 15 flights. As shown in Fig. 2, identification of the plumes was based on a combination of $\mathrm{CO}$ and 


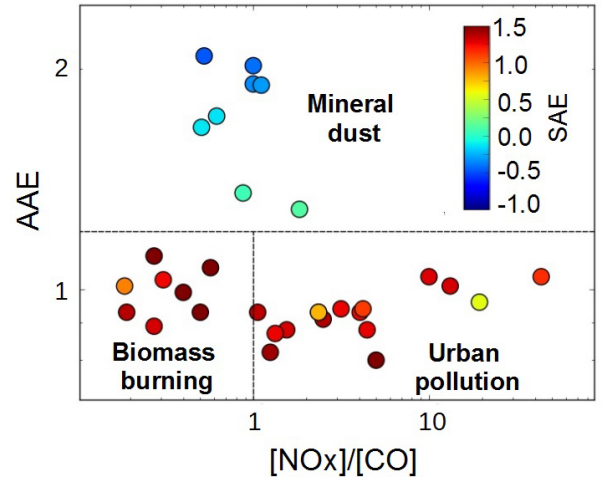

Figure 2. Absorption Ångström exponent (AAE) as a function of the ratio $\mathrm{NO}_{x}$ to $\mathrm{CO}$. The markers are coloured according to the scattering Ångström exponent (SAE). Classification of mineral dust, biomass burning and urban pollution particles has been added to the figure.

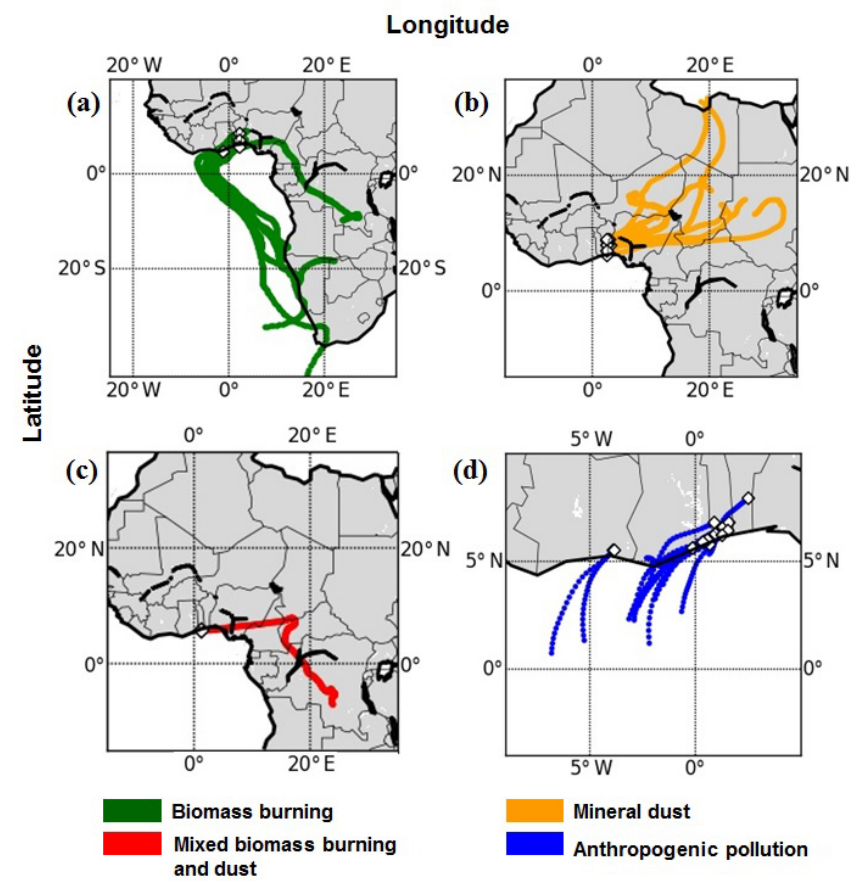

Figure 3. Backward trajectories for the analysed aerosol layers. Trajectories date back $10 \mathrm{~d}$ for panel (a), $5 \mathrm{~d}$ for panels (b) and (c), and $1 \mathrm{~d}$ for panel (d).

$\mathrm{NO}_{x}$ (sum of $\mathrm{NO}$ and $\mathrm{NO}_{2}$ ) concentrations, as well as $\mathrm{AAE}$ and SAE, which have been shown to be good parameters for classifying aerosol types (Kirchstetter et al., 2004; Petzold et al., 2009). The classification was then compared with results from the back-trajectory analysis (Fig. 3) and satellite images described in Sect. 2.2.

The guidelines for classification are as follows.

- Anthropogenic pollution. SAE was beyond threshold 0, indicating a large number fraction of small particles in urban plumes and $\mathrm{CO}$ and $\mathrm{NO}_{x}$ concentrations 2 times higher than the background concentrations. During the DACCIWA campaign background $\mathrm{CO}$ and $\mathrm{NO}_{x}$ values were around 180 and $0.28 \mathrm{ppb}$, respectively. The trajectories show large differences in the flow patterns and source regions, with urban plumes originating from the polluted cities of Lomé, Accra and Abidjan. The aircraft sampling over land mostly followed the north-eastward direction (Fig. 3d).

- Biomass burning. The criteria are the same as for urban pollution plumes except that trajectories track these plumes back to active fire hotspots as observed by MODIS and the ratio $\mathrm{NO}_{x}$ to $\mathrm{CO}$ was set below $1 . \mathrm{CO}$ and $\mathrm{NO}_{x}$ are byproducts of combustion sources, but $\mathrm{CO}$ is preserved longer along the plume when compared with $\mathrm{NO}_{x}$, which makes the ratio $\mathrm{NO}_{x}$ to $\mathrm{CO}$ a good indicator for distinguishing fresh anthropogenic pollution plumes from biomass burning plumes transported over long distances (Wang et al., 2002; Silva and Arellano, 2017). During this time of the year, most of the forest and grassland fires were located in central and southern Africa (Fig. 3a).

- Mineral dust. An AAE higher than 1 indicates a large mass fraction of mineral dust and a SAE below 0 indicates a high effective particle diameter. The source region of the dust-loaded air masses was located in the Saharan desert and in the Sahel (Fig. 3b).

- Dust and biomass burning mixing. Combining remote sensing observations and model simulations, Flamant et al. (2018a) identified a biomass burning plume mixed with mineral dust. This agrees well with the measured AAE of 1.2 and SAE of 0.3 observed in this layer. Menut et al. (2018) have shown that one of the transport pathways of biomass burning aerosols from central Africa was associated with northward advection towards Chad and then westward displacement linked to the African Easterly Jet. The plume originated from a broad active biomass burning area including Gabon, the Republic of Congo and the Democratic Republic of Congo and passed over areas with strong dust emissions further north within $1-3 \mathrm{~d}$ before being sampled by the aircraft (Fig. 3c).

- Background. We refer to background conditions as an atmospheric state in the boundary layer without the detectable influence of mineral dust, biomass burning or local anthropogenic sources. Most back trajectories originated from the marine atmosphere and coastal areas south of the sampling area. 


\section{Results}

\subsection{Aerosol vertical distribution}

Figure 4 shows a statistical analysis of $N_{\text {fine }}, N_{\text {coarse }}$ and $\sigma_{\text {ext }}$ derived from the in situ measurements of vertical profiles. The aerosol vertical structure is strongly related to the meteorological structure of the atmosphere (see Knippertz et al., 2017, for an overview of the DACCIWA field campaign). Therefore wind vector and potential temperature profiles acquired with the aircraft have been added to Fig. 4 as a function of the dominating aerosol composition, introduced in Fig. 1. The data from individual vertical profiles were merged into $200 \mathrm{~m}$ vertical bins from the surface to $6 \mathrm{~km}$ a.m.s.l. The profiles were calculated using only individual profiles obtained outside of clouds.

The observed wind profiles highlight the presence of several distinct layers in the lower troposphere. For cases related to dust, urban pollution and background condition, we clearly observe the monsoon layer up to $1.5 \mathrm{~km}$ a.m.s.l., which is characterized by weak to moderate wind speeds ( 2 to $10 \mathrm{~m} \mathrm{~s}^{-1}$, the latter corresponding to dust cases) and a flow from the south-west $\left(220-250^{\circ}\right)$. In all three air mass regimes, the monsoon layer is topped by a 500 to $700 \mathrm{~m}$ deep layer characterized by a sharp wind direction change (from south-westerly to easterly). Weak wind speeds (less than $5 \mathrm{~m} \mathrm{~s}^{-1}$ ) are observed in urban pollution and background conditions, while higher wind speeds are observed in the dust cases. Above $2.5 \mathrm{~km}$ a.m.s.l., the wind speed increases in the urban pollution and dust cases and the wind remains easterly, indicating the presence of the African Easterly Jet with its core typically farther north over the Sahel (Fig. 8 in Knippertz et al., 2017, for the latitudinal variations of the African Easterly Jet during the DACCIWA field phase). The maximum easterlies are observed in the dust cases slightly below $3.5 \mathrm{~km}$ a.m.s.l. $\left(>15 \mathrm{~m} \mathrm{~s}^{-1}\right)$. For the background cases, the wind above the shear layer shifts to north-westerly and remains weak (i.e. $\sim 5 \mathrm{~m} \mathrm{~s}^{-1}$ ). Overall, the wind profile associated with the biomass burning cases is quite different from the other three cases, with a flow essentially from the southsouth-west below $5 \mathrm{~km}$ a.m.s.l., higher wind speeds in the lower $2 \mathrm{~km}$ a.m.s.l. than above, and a secondary maximum of $7 \mathrm{~m} \mathrm{~s}^{-1}$ at $4 \mathrm{~km}$ a.m.s.l.

The vertical distribution of aerosol particles was very inhomogeneous, both across separate research flights and between individual plumes encountered during different periods of the same flight. Measurements of aerosols within this analysis cover a broad geographic region, as shown in Fig. 1, which may explain some of the variability. SWA is subject to numerous anthropogenic emission sources (e.g. road traffic, heavy industries, open agriculture fires) coupled to biogenic emissions from the ocean and forests. These resulting large emissions are reflected in the high variability of $\sigma_{\text {ext }}, N_{\text {fine }}$ and $N_{\text {coarse }}$ in the lower troposphere over SWA. Below $2.5 \mathrm{~km}$ a.m.s.l., $\sigma_{\mathrm{ext}}$ showed a large hetero- geneity, with values ranging from 35 to $188 \mathrm{Mm}^{-1}$ between the 3rd and 97th percentiles and a median value of $55 \mathrm{Mm}^{-1}$. The variability of $\sigma_{\text {ext }}$ values was slightly enhanced near the surface and was correlated with $N_{\text {fine }}$ and $N_{\text {coarse }}$, which ranged from 443 to $5250 \mathrm{~cm}^{-3}$ and from 0.15 to $1.6 \mathrm{~cm}^{-3}$, respectively. Maximum surface $\sigma_{\text {ext }}$ was recorded in the anthropogenic pollution plume of Accra where high $N_{\text {fine }}$ was sampled. The aerosol vertical profile is strongly modified during biomass burning and dust events. The dust plume extends from 2 to $5 \mathrm{~km}$ a.m.s.l. and is associated with transport from the dust sources in Chad and Sudan (see Fig. 3) with the mid-level easterly flow. The biomass burning plume extends from 1.5 to $5 \mathrm{~km}$ a.m.s.l. and is associated with transport from the south-west in a layer of enhanced wind speed just below $4 \mathrm{~km}$ a.m.s.l. as discussed above. Both layers showed enhanced $\sigma_{\text {ext }}$ with median values of $68 \mathrm{Mm}^{-1}\left(p_{03}=12 \mathrm{Mm}^{-1} ; p_{97}=243 \mathrm{Mm}^{-1}\right)$ in biomass burning plumes and $78 \mathrm{Mm}^{-1}\left(p_{03}=45 \mathrm{Mm}^{-1}\right.$; $\left.p_{97}=109 \mathrm{Mm}^{-1}\right)$ in dust plumes. As expected, the extinction profile was strongly correlated with $N_{\text {fine }}$ for biomass burning layers and $N_{\text {coarse }}$ for dust layers.

A prominent feature in the vertical profiles is the presence of fine particles up to $2.5 \mathrm{~km}$ a.m.s.l. outside of biomass burning or dust events. $\sigma_{\text {ext }}, N_{\text {fine }}$ and $N_{\text {coarse }}$ continuously decrease with altitude, most likely due to vertical mixing of local emissions from the surface to higher levels. Therefore, the regional transport of locally emitted aerosols was not limited to the surface, but occurred also at higher altitudes. Recently, numerical tracer experiments performed for the DACCIWA airborne campaign period have demonstrated that a combination of land-sea surface temperature gradients, orography-forced circulation and the diurnal cycle of the wind along the coastline favour the vertical dispersion of pollutants above the boundary layer during daytime (Deroubaix et al., 2019; Flamant et al., 2018a). Because of these complex atmospheric dynamics, aerosol layers transiting over the Gulf of Guinea in the free troposphere could be contaminated by background or urban pollution aerosols from the major coastal cities.

\subsection{Aerosol size distribution}

Figure 5a shows the range of variability of the number and volume size distributions measured during DACCIWA. These are extracted from the SLRs identified in Fig. 1. Figure $5 \mathrm{~b}$ shows the same composite distribution normalized by $\mathrm{CO}$ concentration in order to account for differences in the amount of emissions from combustion sources.

Considerable variability in the number concentration of the size distributions, up to approximately 2 orders of magnitude, was observed for a large fraction of the measured size range. The size distributions varied both for different aerosol types and for a given aerosol class. This reflects the relatively wide range of different conditions that were observed over 

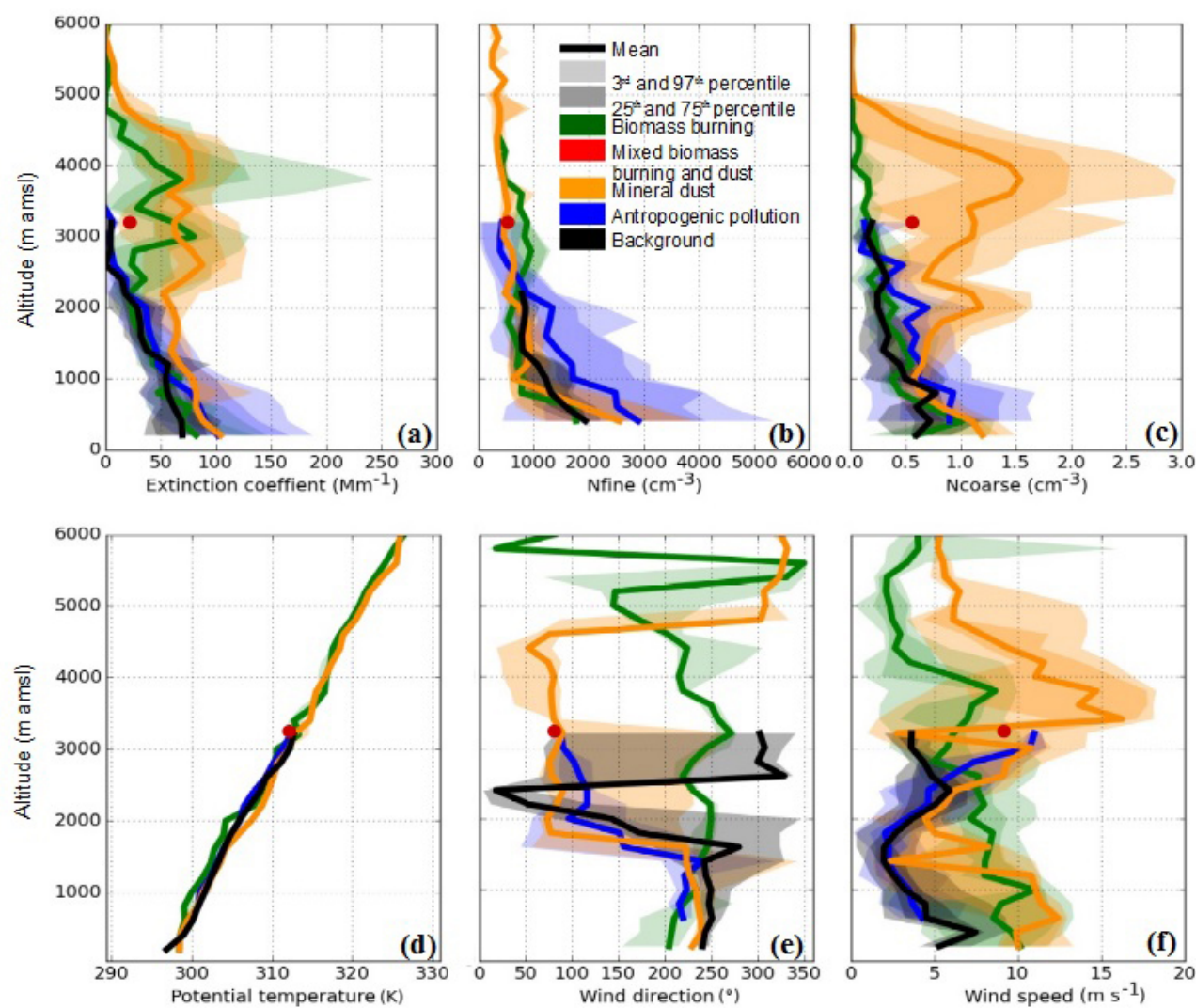

Figure 4. Vertical layering of aerosols and meteorological variables for profiles for which aerosols dominated by biomass burning (green), dust (orange), mixed dust-biomass burning (red), anthropogenic pollution (blue) and background particles (black) were detected. The panels show profiles of (a) the extinction coefficient at $530 \mathrm{~nm}$, (b) the particle number concentration in the range $0.005<D_{p}<1 \mu \mathrm{m}$, (c) the particle number concentration in the range $1<D_{p}<5 \mu \mathrm{m}$, (d) potential temperature, (e) the wind direction and (f) the wind speed. The coloured areas represent the 3rd, 25th, 75th and 97th percentiles of the data. The mixed dust-biomass burning plume is represented by a dot because it is derived from measurements during a SLR.
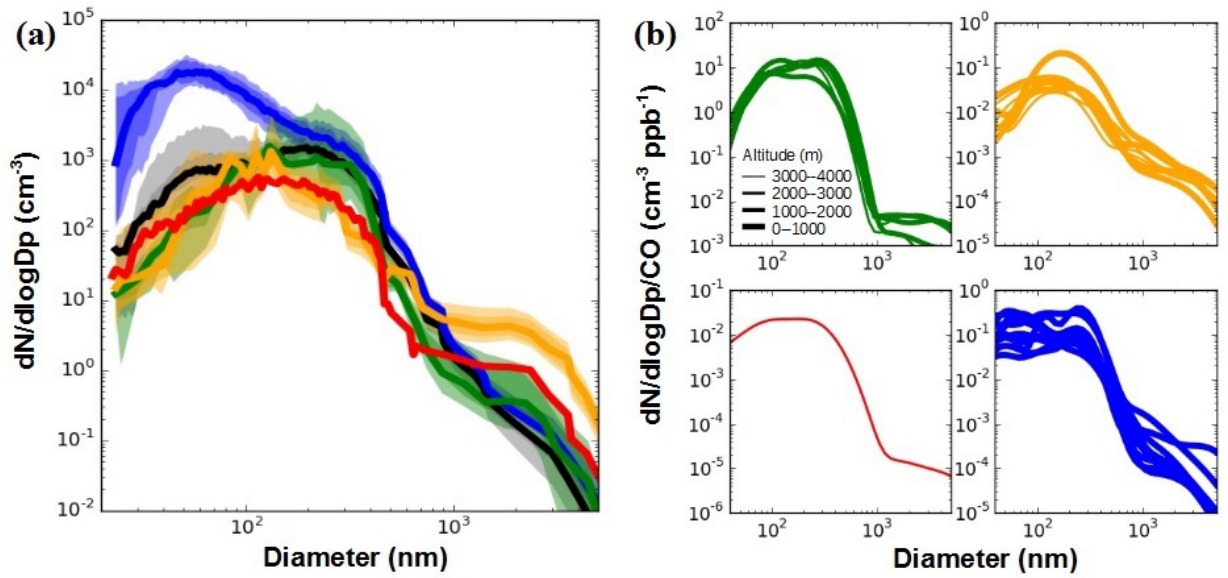

Figure 5. (a) Statistical analysis of number size distributions with coloured areas representing the 3rd, 25th, 75th and 97th percentiles of the data and (b) number size distributions normalized to $\mathrm{CO}$ for plumes dominated by biomass burning (green), dust (orange), mixed dustbiomass burning (red), anthropogenic pollution (blue) and background particles (black). In panel (b), the line thickness is scaled by the altitude of the aerosol plume. 
the region, in terms of sources, aerosol loading, and lifetimes of plumes.

In particular for ultrafine particles with diameters below $100 \mathrm{~nm}$, large differences were observed, with an increase as large as a factor of 50 in urban plumes, which reflects concentration increase from freshly formed particles. Interestingly elevated number concentrations of these smalldiameter particles were also observed in some dust layers. Comparing the particle size distribution of the different dust plumes sampled during the field campaign, a variation as large as a factor of 20 in the number concentration of ultrafine particles is found (i.e. Fig. 4). Their contribution decreased with height, as reflected by the higher small particle number recorded in dust plumes below $2.5 \mathrm{~km}$ a.m.s.l. (Figs. 4b and $5 \mathrm{~b}$ ). As the composite urban size distributions showed a relatively similar ultrafine mode centered at $50 \mathrm{~nm}$, dust layers have most likely significant contributions from anthropogenic pollution aerosol freshly emitted in SWA. The ultrafine mode was not observed in biomass burning size distributions, even though dust and biomass burning plumes were sampled in the same altitude range. We interpret this observation with dust plumes transported below $2.5 \mathrm{~km}$ a.m.s.l. that were sampled over the region of Savè $\left(8^{\circ} 01^{\prime} \mathrm{N}, 2^{\circ} 29^{\prime} \mathrm{E}\right.$; Benin) near the identified urban air mass transported northeastwards from Lomé and/or Accra and which may have collected significant fresh pollution on their way, whereas biomass burning plumes collected at the same altitude and sampled over the Ivory Coast south of the Abidjan pollution plumes may not have been affected by significant direct pollution (Fig. 1).

The accumulation mode was dominated by two modes centered at $D_{p, g} \sim 100$ and $230 \mathrm{~nm}$ depending on the aerosol plume. The particle size distributions for biomass burning plumes were generally dominated by an accumulation mode centered at $D_{p, g} \sim 230 \mathrm{~nm}$. Despite the relatively wide range of sources and lifetimes of the biomass burning plumes sampled throughout the campaign (Fig. 3), the $D_{p, g}$ in the accumulation mode showed little variation ( $D_{p, g}$ from 210 to $270 \mathrm{~nm}$ ) between the plumes. Similarly, previous field studies found accumulation-mode mean diameters from 175 to $300 \mathrm{~nm}$ for aged biomass burning plumes, regardless of their age, transport time and source location (Capes et al., 2008; Janhäll et al., 2010; Weinzierl et al., 2011; Sakamoto et al., 2015; Carrico et al., 2016). The coagulation rate can be very high in biomass burning plumes and can shape the size distribution over a few hours (Sakamoto et al., 2016). It is worth noting that in the biomass burning and dust size distributions there is a persistent particle accumulation mode centered at $\sim 100 \mathrm{~nm}$ that exceeds the number of particles centered at $230 \mathrm{~nm}$ in some layers. This small mode is unlikely to be related to long-range transport of biomass burning and Saharan dust emissions, as it would be expected that particles in this size range would grow to larger particles through coagulation relatively quickly. As similar concentrated accumulation modes of particles have been observed in background plumes, it suggests the entrainment of background air from the boundary layer in dust and biomass burning plumes.

The number concentration of large super-micron particles was strongly enhanced in the mineral dust layers. The peak number concentration displayed a broad shape at $D_{p, g} \sim 1.8 \mu \mathrm{m}$, which is comparable to literature values of other long-range transported dust aerosols (Formenti et al., 2011a; Weinzierl et al., 2011; Ryder et al., 2013; Denjean et al., 2016; Liu et al., 2018). The super-micron mode of the dust plume is expected to be impacted by the mixing with other particles in case of an internal mixing, which should somewhat increase the particle size. The relatively homogeneous $D_{p, g}$ in the coarse mode of dust reported here $\left(D_{p, g}\right.$ from 1.7 to $2.0 \mu \mathrm{m}$ ) suggests low internal mixing with other atmospheric species. Besides, the volume size distribution in urban plumes showed a significant presence $(\sim 65 \%$ of the total aerosol volume) of large particles with diameters of $\sim 1.5-2 \mu \mathrm{m}$, which were also observed in background conditions. We measured AAE in the range $0.7-1$ in anthropogenic pollution plumes (Fig. 2), which suggests negligible contribution of mineral dust in these plumes. This coarse mode has most likely significant contributions from sea salt particles, as plumes arriving from the cities were transported at low altitude over the ocean (Fig. 3).

\subsection{Aerosol optical properties}

SSA is one of the most relevant intensive optical properties because it describes the relative strength of the aerosol scattering and absorption capacity and is a key input parameter in climate models (Solmon et al., 2008). Figure 6 shows the spectral SSA for the different SLRs considered in this study.

The highest absorption (lowest SSA) at all three wavelengths was observed for biomass burning aerosols. SSA values ranged from 0.69 to 0.78 at $440 \mathrm{~nm}, 0.71$ to 0.77 at $550 \mathrm{~nm}$ and 0.65 to 0.76 at $660 \mathrm{~nm}$. This is on the low side of the range of values $(0.73-0.93$ at $550 \mathrm{~nm})$ reported over West Africa during DABEX for biomass burning plumes mixed with variable proportion of mineral dust (Johnson et al., 2008). No clear tendency was found for the spectral dependences of SSA, which in some of the cases decreased with wavelength and in others were very similar to each other at all three wavelengths.

SSA values of anthropogenic pollution aerosols were generally intermediate in magnitude, with median values of 0.81 at $440 \mathrm{~nm}, 0.82$ at $550 \mathrm{~nm}$ and 0.82 at $660 \mathrm{~nm}$. Our data show that the value of SSA varied significantly for the different plumes. Some pollution aerosols absorb almost as strongly as biomass burning aerosols with $\mathrm{SSA}(550 \mathrm{~nm})$ values as low as 0.72 , whereas the highest $\operatorname{SSA}(550 \mathrm{~nm})$ value observed was 0.86. In addition, the absorption properties of urban aerosol varied greatly between the sampled plumes for smoke of an apparently identical geographic origin. For example, we measured SSA $(550 \mathrm{~nm})$ values from 0.72 to 0.82 in the Accra pollution outflow. The variability in SSA values may be 

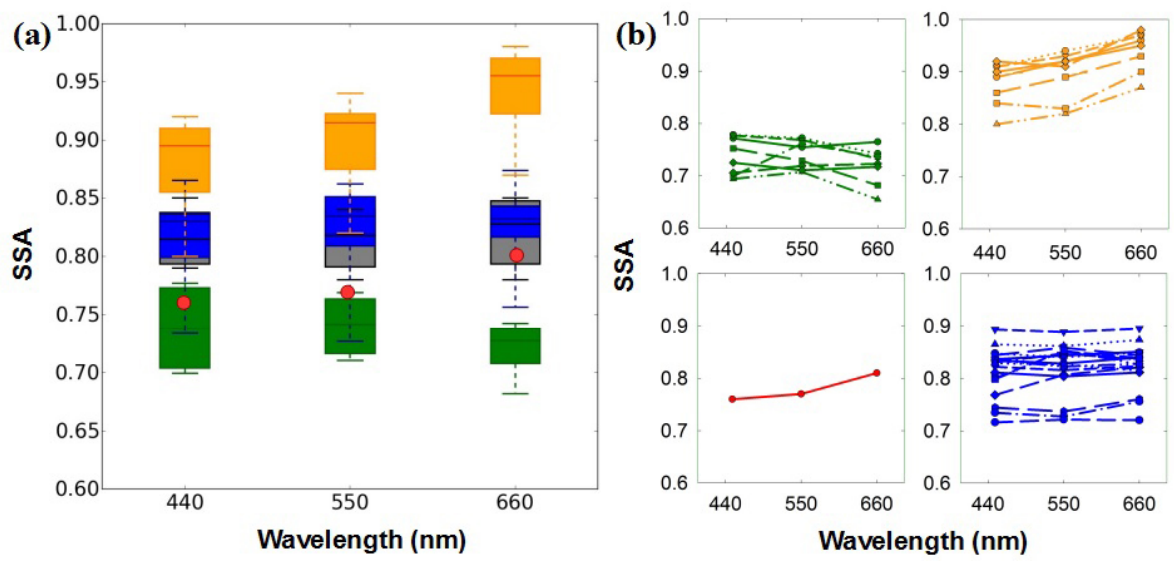

Figure 6. (a) Statistical analysis of single scattering albedo at 450,550 and $660 \mathrm{~nm}$ for plumes dominated by biomass burning (green), dust (orange), mixed dust-biomass burning (red), anthropogenic pollution (blue) and background particles (black). The boxes enclose the 25th and 75th percentiles, the whiskers represent the 5th and 95th percentiles and the horizontal bar represents the median. (b) Spectral SSA for the different individual plumes considered in this study. The mixed dust-biomass burning plume is represented by a dot because it is derived from measurements during only one SLR.

due to the possible contribution of emissions from different cities to the sampled pollution plumes (Deroubaix et al., 2019), thus having different combustion sources and chemical ages. The flat spectral dependence of SSA appears to be anomalous for anthropogenic pollution aerosols, as SSA has been shown to decrease with increasing wavelength for a range of different urban pollution plumes (Dubovick et al., 2002; Petzold et al., 2011; Di Biagio et al., 2016; Shin et al., 2019).

The magnitude of SSA increased at the three wavelengths when dust events occurred. Large variations in SSA were obtained, with values ranging from 0.76 to 0.92 at $440 \mathrm{~nm}$, from 0.81 to 0.94 at $550 \mathrm{~nm}$ and from 0.81 to 0.97 at $660 \mathrm{~nm}$. The measurement of SSA is highly dependent on the extent to which the coarse mode is measured behind the aerosol sampling inlet. Denjean et al. (2016) found that the absolute error associated with SSA, $g$ and MEE of dust aerosols due to the CAI inlet is in the range covered by the measurement uncertainties. However, different aerosol inlet systems were used during previous field campaigns, which makes comparison of our results with previous measurements difficult. Overall, compared with the literature for transported dust, lower values were obtained in the present study for few cases. For example, Chen et al. (2011) reported SSA (550 nm) values of $0.97 \pm 0.02$ during NAMMA (a part of AMMA operated by NASA) using an inlet with a comparable sampling efficiency. The lower values from DACCIWA reflect inherently more absorbing aerosols in some dust plumes. In contrast to fire plumes, the SSA of dust aerosol showed a clear increasing trend with wavelength. This behaviour is likely due to the domination of large particles in dust aerosol, which is in agreement with similar patterns observed in dust source regions (Dubovik et al., 2002). Moreover, an increase in SSA is observed with wavelength for mixed dust-smoke aerosol, suggesting that the aerosol particles were predominantly from dust, albeit mixed with a significant loading of biomass burning.

As shown in Table 2, the observed variability of SSA reflects a large variability for MEE at $550 \mathrm{~nm}$, which spans a wide range from 0.38 to $1.37,1.45$ to 1.92 and 1.24 to $4.83 \mathrm{~m}^{2} \mathrm{~g}^{-1}$ for dust and biomass burning for anthropogenic polluted aerosols, respectively. MEE is heavily influenced by the mass concentrations in the accumulation mode where the aerosol is optically more efficient in extinguishing radiation. We found MEE to be positively correlated with SAE (not shown), which was expected because of the dependence of MEE on particle size. In contrast, the values of $g$ appear to differ only little between the sampled plumes for a given aerosol class. We found $g$ in the range of $0.67-0.76$ for dust, $0.65-0.68$ for biomass burning and 0.59-0.64 for anthropogenic polluted aerosols at $550 \mathrm{~nm} . g$ values in dust plumes were high, which is expected due to the presence of coarse particles contributing to forward scattering.

This analysis includes sampled aerosols originating from different source regions and having undergone different aging and mixing processes, which could explain some of the variability. The impact of these factors on the magnitude and spectral dependence of optical parameters will be investigated in the following section.

\section{Discussion}

\subsection{Contribution of local anthropogenic pollution on aerosol absorption properties}

Figure 7 shows the vertical distribution of SSA, SAE and the $\mathrm{NO}_{x}$ mixing ratio for the dominant aerosol classifica- 
Table 2. Single scattering albedo, mass extinction efficiency (in $\mathrm{m}^{2} \mathrm{~g}^{-1}$ ), asymmetry parameter and scattering Ångström exponent for the dominant aerosol classification.

\begin{tabular}{|c|c|c|c|c|c|c|c|c|c|c|c|}
\hline & & $\operatorname{SSA}(450)$ & $\operatorname{SSA}(550)$ & $\operatorname{SSA}(660)$ & $\operatorname{MEE}(450)$ & $\operatorname{MEE}(550)$ & $\operatorname{MEE}(660)$ & $g(450)$ & $g(550)$ & $g(660)$ & SAE \\
\hline \multirow[t]{5}{*}{ Mineral dust } & median & 0.88 & 0.90 & 0.93 & 0.74 & 0.68 & 0.66 & 0.74 & 0.72 & 0.69 & -0.35 \\
\hline & $3 \mathrm{rd}$ & 0.82 & 0.82 & 0.86 & 0.38 & 0.38 & 0.39 & 0.69 & 0.67 & 0.65 & -0.56 \\
\hline & 25 th & 0.85 & 0.87 & 0.90 & 0.43 & 0.43 & 0.43 & 0.73 & 0.72 & 0.67 & -0.48 \\
\hline & 75th & 0.91 & 0.93 & 0.96 & 0.94 & 0.85 & 0.85 & 0.75 & 0.74 & 0.72 & -0.25 \\
\hline & 97th & 0.92 & 0.95 & 0.97 & 1.57 & 1.37 & 1.21 & 0.78 & 0.76 & 0.72 & -0.12 \\
\hline \multirow{5}{*}{$\begin{array}{l}\text { Biomass } \\
\text { burning }\end{array}$} & median & 0.74 & 0.76 & 0.72 & 1.91 & 1.62 & 1.34 & 0.69 & 0.68 & 0.61 & 1.07 \\
\hline & 3rd & 0.70 & 0.72 & 0.66 & 0.94 & 1.45 & 1.22 & 0.64 & 0.65 & 0.59 & 0.59 \\
\hline & 25 th & 0.70 & 0.76 & 0.71 & 1.67 & 1.48 & 1.27 & 0.69 & 0.65 & 0.60 & 0.83 \\
\hline & 75 th & 0.77 & 0.77 & 0.74 & 1.86 & 1.65 & 1.55 & 0.72 & 0.68 & 0.62 & 1.15 \\
\hline & 97th & 0.78 & 0.77 & 0.76 & 2.38 & 1.92 & 1.58 & 0.73 & 0.68 & 0.63 & 1.64 \\
\hline \multirow{5}{*}{$\begin{array}{l}\text { Mixed dust - } \\
\text { Biomass } \\
\text { burning }\end{array}$} & median & 0.76 & 0.77 & 0.81 & 1.58 & 1.40 & 1.30 & 0.73 & 0.66 & 0.64 & 0.38 \\
\hline & $3 r d$ & - & - & - & - & - & - & - & - & - & - \\
\hline & 25 th & - & - & - & - & - & - & - & - & - & - \\
\hline & 75th & - & - & - & - & - & - & - & - & - & - \\
\hline & 97th & - & - & - & - & - & - & - & - & - & - \\
\hline \multirow{5}{*}{$\begin{array}{l}\text { Anthropogenic } \\
\text { Pollution }\end{array}$} & median & 0.83 & 0.84 & 0.85 & 2.60 & 2.49 & 1.90 & 0.60 & 0.61 & 0.62 & 0.75 \\
\hline & 3rd & 0.78 & 0.79 & 0.81 & 0.70 & 1.24 & 0.54 & 0.60 & 0.59 & 0.54 & 0.30 \\
\hline & 25 th & 0.80 & 0.82 & 0.83 & 2.14 & 2.25 & 1.53 & 0.62 & 0.60 & 0.56 & 0.65 \\
\hline & 75 th & 0.84 & 0.86 & 0.85 & 3.51 & 2.96 & 2.53 & 0.69 & 0.62 & 0.67 & 0.89 \\
\hline & 97th & 0.87 & 0.88 & 0.90 & 3.70 & 4.83 & 2.74 & 0.73 & 0.64 & 0.70 & 0.94 \\
\hline
\end{tabular}

tion. We exclusively consider measurements acquired during SLRs, since only during these phases was the whole set of aerosol optical properties measured. In dust plumes, if we exclude the case of mixing with biomass burning aerosol, SSAs were fairly constant above $2.5 \mathrm{~km}$ a.m.s.l., with values ranging between 0.90 and 0.93 at $550 \mathrm{~nm}$, in agreement with values reported over dust source regions (Schladitz et al., 2009; Formenti et al., 2011b; Ryder et al., 2013, 2018). Despite the range of sources identified during DACCIWA, dust absorption properties do not seem to be clearly linked to particle origin or time of transport. Aerosols were more absorbing within the low-altitude dust plumes, with SSA values dropping to 0.81 . SAE values exhibited simultaneously a sharp increase close to zero below $2.5 \mathrm{~km}$ a.m.s.l. This is consistent with a higher concentration of fine particles, though the value of SAE was still much lower than for pollution or background aerosol (i.e. where it is typically $>0.2$ ), which means that scattering was still dominated by larger particles. Based on the whole sets of observations, the strong variation in the light-absorption properties of dust-dominated aerosol over SWA could be attributed to the degree of mixing into the vertical column with either freshly emitted aerosols from urban/industrial sources or long-range transported biomass burning aerosol.

One of the critical factors in the calculation of aerosol direct and semi-direct radiative effects is the mixing state of the aerosols, which can significantly affect absorbing properties. There were no direct observational constraints available on this property during the DACCIWA airborne campaign. However, we investigated the probable aerosol mixing state by calculating composite SSA from the aerosol size distribution. On the basis of Fig. 5, dust size distributions showed only minor discrepancies in the mean and standard deviation of the coarse mode but significant differences in the balance between the fine and coarse modes, which suggests low internal mixing of dust with other atmospheric species. The size distributions of mixed dust pollution have been deconvoluted by weighting the size distributions of mineral dust and anthropogenic pollution aerosol averaged over the respective flights. This assumes that dust was externally mixed with the anthropogenic pollution particles and assumes a homogeneous size distribution for the dust and anthropogenic pollution aerosol throughout a flight. $\sigma_{\text {scat }}$ and $\sigma_{\text {abs }}$ were then calculated using Mie theory from each composite size distribution and the corresponding $k$ and $m$. The refractive indices at $550 \mathrm{~nm}$ were assumed to be $1.52-0.002 i$ and $1.60-0.040 i$ for dust and anthropogenic pollution particles, respectively, which are the mean values deduced from the data inversion procedure (i.e. Sect. 2.3.1) throughout the campaign. The resulting $\sigma_{\text {scat }}$ and $\sigma_{\text {abs }}$ were used to calculate a composite SSA. A similar calculation was performed for the mixed dustbiomass burning case. Figure 7 shows a good agreement with the observations of SSA, implying that external mixing appears to be a reasonable assumption to compute aerosol direct and semi-direct radiative effects in these dust layers for modelling applications. This is consistent with the filter analysis performed during AMMA and SAMUM-2, which did not reveal any evidence of internal mixing in both mixed dust-biomass burning and dust-anthropogenic pollution layers (Chou et al., 2008; Lieke et al., 2011; Petzold et al., 2011). 

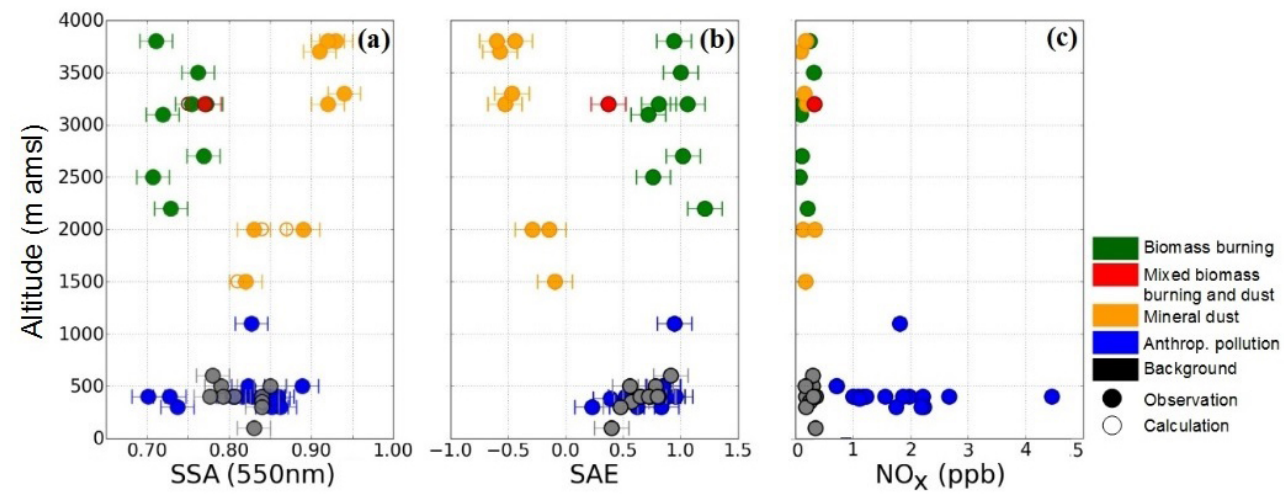

Figure 7. Vertical distribution of (a) the single scattering albedo at $550 \mathrm{~nm}$, (b) the scattering Ångstrom exponent and (c) the $\mathrm{NO}_{x}$ mixing ratio for the dominant aerosol classification. In panel (a), full circles represent SSA measurements and empty circles represent composite SSA calculated by deconvoluting size-distribution measurements in mixed dust layers and assuming an external mixing state.

SSA, SAE and $\mathrm{NO}_{x}$ of biomass burning plumes did not significantly vary with height from 2.2 to $3.8 \mathrm{~km}$ a.m.s.l. Moreover, the size distribution of biomass burning aerosols for the observed cases did not show a significant contribution of ultrafine particles (Fig. 5). These observations seem to indicate that the absorption properties of biomass burning plumes were not affected by direct pollution emissions.

In the boundary layer, the similar SSA and SAE in anthropogenic pollution and background plumes suggest that background aerosol may be rather called background pollution originating from a regional background source in the far field. Our analysis of the spectral dependence of SSA showed no apparent signature of anthropogenic pollution aerosols (see Sect. 3.3) despite a strong increase in aerosol number concentrations in air masses crossing urban centres (see Sect. 3.2). This can be explained by two factors. First, the majority of accumulation-mode particles were present in the background, while the large proportion of aerosols emitted from cities resided in the ultrafine-mode particles that have fewer scattering efficiencies (Fig. 5). Second, large amounts of absorbing aerosols in the background can minimize the impact of further increase in absorbing particles to the aerosol load. The high CO values $(\sim 180 \mathrm{ppb})$ observed in background conditions further indicate a strong contribution of combustion emissions at the surface. Recent studies showed a large background of biomass burning transported from the Southern Hemisphere in SWA that dominated the aerosol chemical composition in the boundary layer (Menut et al., 2018; Haslett et al., 2019). The high absorbing properties (SSA $\sim 0.81$ at $550 \mathrm{~nm}$ ) and the presence of particles in both the accumulation and super-micron modes (i.e. Sect. 3.2) in background plumes are consistent with being a mixture of aged absorbing biomass burning and Atlantic marine aerosol. These results highlight that aerosol optical properties at the surface were dominated by the widespread biomass burning particles at regional scale.

\subsection{Aging as a driver for absorption enhancement of biomass burning aerosol}

The optical properties of aerosols are determined by either the aerosol chemical composition, the aerosol size distribution, or both. Changes in the size distribution of biomass burning aerosol due to coagulation and condensation have been shown to alter the SSA, as particles increase towards sizes for which scattering is more efficient (Laing et al., 2016). Variations in particle chemical composition, caused by source emissions and aging processes associated with gas-to-particle transformation and internal mixing, have been shown to change the SSA (Abel et al., 2003; Petzold et al., 2011).

In order to determine the contributions from size distribution and chemical composition to the variation of SSA in biomass burning plumes, SSA is presented as a function of $\mathrm{SAE}$ and $k$ in Fig. $7 \mathrm{a}$ and $\mathrm{b}$, respectively. $k$ was iteratively varied to reproduce the experimental scattering and absorption coefficients, as described in Sect. 2.3.1. It appears that the variation of the size distribution (assessed via SAE in Fig. 8a) had minimal impact in determining the variability of SSA. Thus, the observations suggest that there was no effect of plume age on the size distribution, consistent with previous observations of size distribution in aged North American biomass burning plumes (Sakamoto et al., 2015; Carrico et al., 2016; Laing et al., 2016). Using a Lagrangian microphysical model, Sakamoto et al. (2015) have shown a rapid shift to larger sizes for biomass burning plumes within the first hours of aging. Less drastic but similarly rapid growth by coagulation was seen by Capes et al. (2008) in their box model. Given that the biomass burning plumes sampled during DACCIWA had more than $5 \mathrm{~d}$ in age, the quick sizedistribution evolution within the early plume stages might explain the limited impact of the size distribution on the SSA.

In contrast, Fig. $8 \mathrm{~b}$ shows that there was a consistent decrease in SSA with increasing $k$, although there is some vari- 

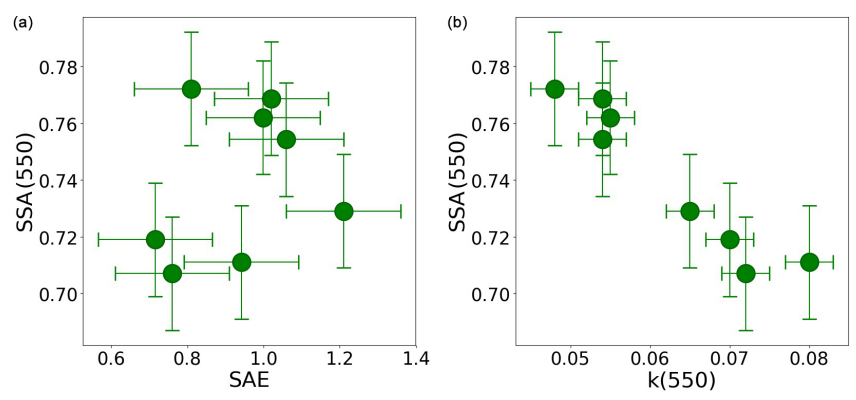

Figure 8. Contribution to single scattering albedo (a) from particle size (assessed via SAE) and (b) from composition (assessed via $k$ ) in biomass burning plumes.

ability between the results from different plumes. The observed variability of SSA is reflected in a large variability of $k$, which is estimated to span the large range $0.048-0.080$ at $550 \mathrm{~nm} . k$ depends both on the aerosol chemical composition and size distribution (Mita and Isono, 1980). Given that SSA was found to be independent of the aerosol size distribution (Fig. 8a), Fig. 8b suggests that SSA variability was strongly influenced by the variability in composition of biomass burning aerosol, implying a high contribution for light-absorbing particles. No clear tendency was found for the wavelength dependence of $k$, which in some of the cases increases with wavelength and in others decreases (not shown). In field observation, significant absorption and strong spectral dependence (values of AAE > 1.7) in biomass burning plumes have been frequently attributed to the presence of brown carbon (BrC) (Kirchstetter et al., 2004; Sandradewi et al., 2008; Romonosky et al., 2019; Chakrabarty et al., 2010; Pokhrel et al., 2016). Contrary to the current understanding, our measurements show that the contribution of $\mathrm{BrC}$ to light absorption is negligible as AAE values ranged from 0.9 to 1.1 with a median value of 1.0. (Fig. 2b). Theoretically, fine-mode aerosol with absorption determined exclusively by $\mathrm{BC}$ would have an $\mathrm{AAE}$ equal to 1.0 , since $\mathrm{BC}$ is expected to have a spectrally constant $k$ (Bond et al., 2013). Therefore, the low SSA values observed in biomass burning plumes over SWA and the small spectral variation of $k$ both suggest that BC is the dominant absorber in the visible and near-IR (infrared) wavelengths for these biomass burning aerosols.

Compared with past in situ measurements of aged biomass burning aerosol, SSA values over SWA (0.71-0.77 at $550 \mathrm{~nm})$ are at the lower end of those reported worldwide (0.73-0.99 at 550 nm) (Magi et al., 2003; Reid et al., 2005; Johnson et al., 2008; Corr et al., 2012; Laing et al., 2016). This can be attributed in part to the high flaming versus smouldering conditions of African smoke producing more BC particles (Andreae and Merlet, 2001; Reid et al., 2005), which inherently have low SSA compared to other regions (Dubovick et al., 2002). However, SSA values over SWA are significantly lower than the range reported near emission sources in sub-Saharan Africa and over the south-eastern At- lantic, where values span over $0.84-0.90$ at $550 \mathrm{~nm}$ (Haywood et al., 2003b; Pistone et al., 2019). Recent observations carried out on Ascension Island to the south-west of the DACCIWA region showed that smoke transported from central and southern African fires can be very light absorbing over the July-November burning season, but SSA values were still higher $(0.80 \pm 0.02$ at $530 \mathrm{~nm}$; Zuidema et al., 2018) than those reported over SWA. A possible cause of the lower SSA in SWA is that Ascension Island is much closer to the local sources and the aerosol is therefore less aged.

Currently there are few field measurements of well-aged biomass burning emissions. Our knowledge of biomass burning aerosol primarily comes from laboratory experiments and near-field measurements taken within a few hours of a wildfire (Abel et al., 2003; Yokelson et al., 2009; Adler et al., 2011; Haywood et al., 2003b; Vakkari et al., 2014; Zhong and Jang, 2014; Forrister et al., 2015; Laing et al., 2016; Zuidema et al., 2018). With the exception of the study by Zuidema et al. (2018) over the south-eastern Atlantic, it is generally found that the aged biomass burning aerosol particles are less absorbing than freshly emitted aerosols due to a combination of condensation of secondary organic species and an additional increase in size by coagulation. This is in contrast to our results showing that SSA of biomass burning aerosols was significantly lower than directly after emission and that the evolution of SSA occurred a long time after emission.

There are three possible explanations for these results. First, one must consider sample bias. As regional smoke ages, it can be enriched by smoke from other fires that can smoulder for days, producing large quantities of nonabsorbing particles, thereby increasing the mean SSA (Reid et al., 2005; Laing et al., 2016). However, during DACCIWA, biomass burning plumes were transported over the Atlantic Ocean and were probably less influenced by multiple fire emissions. Second, there is evidence that fresh BC particles become coated with sulfate and organic species as the plume ages in a manner that enhances their light absorption (Lack et al., 2012; Schwarz et al., 2008). Finally, organic particles produced during the combustion phase can be lost during the transport through photobleaching, volatilization and/or cloud-phase reactions (Clarke et al., 2007; Lewis et al., 2008; Forrister et al., 2015), which is consistent with the low SSA and AAE values we observed. Assessing whether these aging processes impact the chemical components and henceforth optical properties of transported biomass burning aerosol would need extensive investigation of aerosol chemical composition that will be carried out in a subsequent paper.

\section{Conclusions}

This paper provides an overview of in situ airborne measurements of vertically resolved aerosol optical properties carried out over SWA during the DACCIWA field campaign in 
June-July 2016. The peculiar dynamics of the region lead to a chemically complex situation, which enabled sampling of various air masses, including long-range transport of biomass burning from central Africa and dust from Sahelian and Saharan sources, local anthropogenic plumes from the major coastal cities, and mixtures of these different plumes. This work fills a research gap by providing, firstly, key climaterelevant aerosol properties (SSA, MEE, $g$, SAE, AAE), and secondly, observations of the impact of aging and mixing processes on aerosol optical properties.

The aerosol vertical structure was very variable and mostly influenced by the origin of air mass trajectories. While aerosol extinction coefficients generally decreased with height, there were distinct patterns of profiles during dust and biomass burning transport to SWA. When present, enhanced values of extinction coefficients up to $240 \mathrm{Mm}^{-1}$ were observed in the $2-5 \mathrm{~km}$ a.m.s.l. range. These elevated aerosol layers were dominated by either dust or biomass burning aerosols, which is consistent with what would be expected on the basis of the atmospheric circulations during the monsoon season (McConnell et al., 2008; Knippertz et al., 2017). However, during one flight a mixture of dust and biomass burning was found in a layer at around $3 \mathrm{~km}$ a.m.s.l., implying that there may be substantial variability in the idealized picture. In the lower troposphere, the large anthropogenic pollution plumes extended as far as hundreds of kilometres from the cities' emission sources and were not limited to the boundary layer, but occurred also at higher levels up to $2.5 \mathrm{~km}$ a.m.s.l., which is explained by vertical transport and mixing processes, partly triggered by the orography of SWA (Deroubaix et al., 2019; Flamant et al., 2018a). The analysis of the aerosol size distributions, $\mathrm{SAE}$ and $\mathrm{NO}_{x}$ suggests a strong mixing of dust with anthropogenic pollution particles in dust layers transported below $2.5 \mathrm{~km}$ a.m.s.l., whereas biomass burning plumes that were transported more northward were not affected by this mixing. Both transport pathways and vertical structures of biomass burning and dust plumes over SWA appear to be the main factors affecting the mixing of anthropogenic pollution with dust and biomass burning particles.

The aerosol light absorption in dust plumes was strongly enhanced as a result of this mixing. We find a decrease in $\mathrm{SSA}(550 \mathrm{~nm})$ from 0.92 to 0.81 for dust affected by anthropogenic pollution mixing compared to the situation in which the dust plumes moved at higher altitudes across SWA. Comparison of the particle size distributions of the different dust plumes showed a large contribution of externally mixed finemode particles in mixed layers, while there was no evidence of internal mixing of coarse particles. Concurrent optical calculations by deconvoluting size-distribution measurements in mixed layers and assuming an external mixing state allowed us to reproduce the observed SSAs. This implies that an external mixing would be a reasonable assumption to compute aerosol direct and semi-direct radiative effects in mixed dust layers.
Despite a strong increase in aerosol number concentration in air masses crossing urban conglomerations, the magnitude of the spectral SSAs was comparable to the background. Enhancements of light absorption properties were seen in some pollution plumes but were not statistically significant. A persistent spectral signature of biomass burning aerosols in both background and pollution plumes highlights that the aerosol optical properties in the boundary layer were strongly affected by the ubiquitous biomass burning aerosols transported from central Africa (Menut et al., 2018; Haslett et al., 2019). The large proportion of aerosols emitted from the cities of Lomé, Accra and Abidjan that resided in the ultrafine-mode particles have limited impact on already elevated amounts of accumulation-mode particles having a maximal absorption efficiency. As a result, in the boundary layer, the contributions from local city emissions to aerosol optical properties were of secondary importance at regional scale compared with this large absorbing aerosol mass. While local anthropogenic emissions are expected to rise as SWA is currently experiencing major economic and population growth, there is increasing evidence that climate change is increasing the frequency and distribution of fire events (Jolly et al., 2015). In terms of future climate scenarios and accompanying aerosol radiative forcing, whether the large biomass burning events that occur during the monsoon season would limit the radiative impact of increasing anthropogenic emissions remains an open and important question.

The SSA values of biomass burning aerosols transported in the free troposphere were very low $(0.71-0.77$ at $550 \mathrm{~nm})$ and have only rarely been observed in the atmosphere. The variability in SSA was mainly controlled by the variability in aerosol composition (assessed via $k$ ) rather than by variations in the aerosol size distribution. Correspondingly, values of AAE ranged from 0.9 to 1.1, suggesting that $\mathrm{BC}$ particles were the dominant absorber in the visible region for these biomass burning aerosols. In recent years the southern Atlantic Ocean, especially the area of the western coast of Africa, has become an increasing focus in the research community, through the ORACLES/LASIC (ObseRvations of Aerosols above CLouds and their intEractionS/Layered Atlantic Smoke Interactions with Clouds), AEROCLO-sA (AErosol RadiatiOn and CLOuds in Southern Africa - AEROCLO-SA) and CLARIFY (Cloud and Aerosols Radiative Impact and Forcing) projects (Zuidema et al., 2016, 2018; Formenti et al., 2019). Comparison with the literature showed a consistent picture of increasing absorption enhancement of biomass burning aerosol from emission to remote locations. Further, the range of SSA values over SWA was slightly lower than that reported on Ascension Island to the south-west of the DACCIWA region, which underscores that the evolution of SSA occurred a long time after emission. While the mechanism responsible for this phenomenon warrants further study, our results support the growing body of evidence that the optical parameters used in regional/global climate modelling studies, especially ab- 
sorption by biomass burning aerosols, have to be better constrained using these recent observations to determine the direct and semi-direct radiative effects of smoke particles over this region (Mallet et al., 2019). In particular and regarding the very high absorbing properties of smoke, specific attention should be dedicated to the semi-direct effect of biomass burning aerosols at the regional scale and its relative contribution to the indirect radiative effect.

We believe the set of DACCIWA observations presented here is representative of the regional mean and variability in aerosol optical properties that can be observed during the monsoon season over SWA, as the main dynamical features were in line with the climatology (Knippertz et al., 2017). This is why results from the present study will serve as input and constraints for climate modelling to better understand the impact of aerosol particles on the radiative balance and cloud properties over this region and will also substantially support remote sensing retrievals. 


\section{Appendix A}

Table A1. Summary of flight information. All flights were conducted during 2016.

\begin{tabular}{|c|c|c|c|c|}
\hline $\begin{array}{l}\text { Flight } \\
\text { number }\end{array}$ & Date & $\begin{array}{r}\text { Take off } \\
\text { time (UTC) }\end{array}$ & $\begin{array}{r}\text { Landing } \\
\text { time (UTC) }\end{array}$ & Events observed \\
\hline F17 & 29 June & $14: 17$ & $17: 10$ & Export of pollution from Lomé \\
\hline F18 & 30 June & $12: 52$ & $16: 29$ & Export of pollution from Lomé \\
\hline F19 & 1 July & $10: 35$ & 14:06 & Export of pollution from Accra \\
\hline F20 & 2 July & 09:53 & $13: 21$ & $\begin{array}{l}\text { Export of pollution from Lomé } \\
\text { Dust outbreak }\end{array}$ \\
\hline $\mathrm{F} 21$ & 2 July & $15: 04$ & $18: 29$ & $\begin{array}{l}\text { Export of pollution from Lomé } \\
\text { Biomass burning outbreak } \\
\text { Mixed dust-biomass burning outbreak }\end{array}$ \\
\hline $\mathrm{F} 22$ & 3 July & 09:54 & $13: 29$ & Export of pollution from Lomé \\
\hline F24 & 6 July & 07:17 & $11: 03$ & Export of pollution from Abidjan \\
\hline $\mathrm{F} 27$ & 8 July & 05:52 & 09:28 & Export of pollution from Accra \\
\hline F28 & 8 July & $10: 53$ & $14: 22$ & Dust outbreak \\
\hline F29 & 10 July & $10: 31$ & $14: 11$ & $\begin{array}{l}\text { Export of pollution from Lomé } \\
\text { Dust outbreak }\end{array}$ \\
\hline F30 & 11 July & $07: 19$ & 11:01 & $\begin{array}{l}\text { Export of pollution from Abidjan } \\
\text { Biomass burning outbreak }\end{array}$ \\
\hline F31 & 11 July & $13: 48$ & $16: 42$ & Biomass burning outbreak \\
\hline F32 & 12 July & $13: 56$ & $17: 20$ & Export of pollution from Accra \\
\hline F33 & 13 July & $12: 40$ & $16: 11$ & Biomass burning outbreak \\
\hline F35 & 15 July & $09: 32$ & $13: 00$ & Export of pollution from Lomé \\
\hline
\end{tabular}

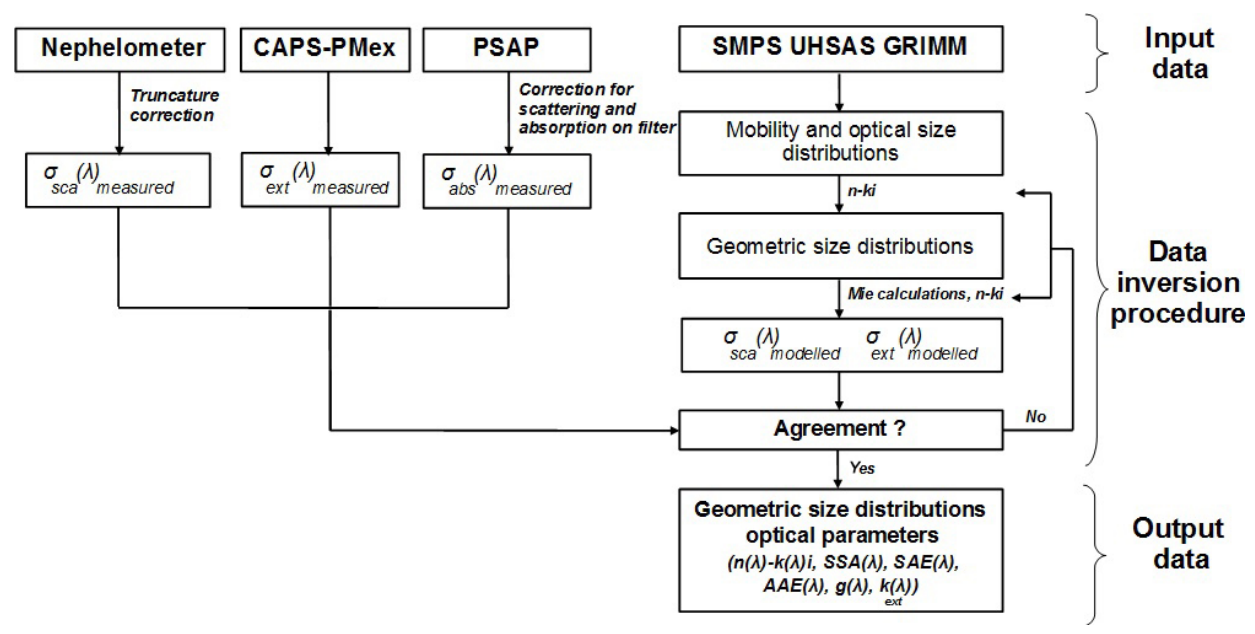

Figure A1. Data inversion procedure to calculate the aerosol microphysical and optical parameters. 
Data availability. All data used in this study are publicly available at the AERIS Data and Service Center, which can be found at http: //baobab.sedoo.fr/DACCIWA (last access: 20 April 2020; Colomb and Piguet, 2017; Denjean and Bourrianne, 2017a, b; Ramonet et al., 2017; Schwarzenboeck and Dupuy, 2017a, b, c).

Author contributions. CD conducted the analysis of the data and wrote the paper. CD, TB, FB, NM, AC, PD, JB, RD, KS and AS operated aircraft instruments and processed and/or quality-controlled data. MM provided expertise on aerosol-climate interaction processes. CF and PK were the PIs, who led the funding application and coordinated the DACCIWA field campaign. All the co-authors contributed to the writing of the paper.

Competing interests. The authors declare that they have no conflict of interest.

Special issue statement. This article is part of the special issue "Results of the project "Dynamics-aerosol-chemistry-cloud interactions in West Africa" (DACCIWA) (ACP/AMT inter-journal SI)". It is not associated with a conference.

Acknowledgements. The research leading to these results has received funding from the European Union 7th Framework Programme (FP7/2007-2013) under grant agreement no. 603502 (EU project DACCIWA: Dynamics-Aerosol-Chemistry-Cloud Interactions in West Africa). The European Facility for Airborne Research (EUFAR, http://www.eufar.net/, last access: 17 April 2020) also supported the project through the funding of Transnational Activity projects OLACTA and MICWA. We thank the Service des Avions Français Instrumentés pour la Recherche en Environnement (SAFIRE, a joint entity of CNRS, Météo-France, and CNES) and operator of the ATR-42 for their support during the aircraft campaign. Cyrielle Denjean thanks CNES for financial support. The authors would like to thank Bruno Piguet (CNRM) and Michel Ramonet (LSCE) for their support in the data processing.

Financial support. This research has been supported by the FP7 Environment (DACCIWA (grant no. 603502)).

Review statement. This paper was edited by Andreas Petzold and reviewed by two anonymous referees.

\section{References}

Abel, S. J., Haywood, J. M., Highwood, E. J., Li, J., and Buseck, P. R.: Evolution of biomass burning aerosol properties from anagricultural fire in southern Africa, Geophys. Res. Lett., 30, 1783, https://doi.org/10.1029/2003GL017342, 2003.

Adler, G., Flores, J. M., Abo Riziq, A., Borrmann, S., and Rudich, Y.: Chemical, physical, and optical evolution of biomass burn- ing aerosols: a case study, Atmos. Chem. Phys., 11, 1491-1503, https://doi.org/10.5194/acp-11-1491-2011, 2011.

Andreae, M. O. and Merlet, P.: Emission of Trace Gases and Aerosols from Biomass Burning, Global Biogeochem. Cy., 15, 955-966, 2001.

Ansmann, A., Petzold, A., Kandler, K., Tegen, I. N. A., Wendisch, M., Müller, D., Weinzierl, B., Müller, T., and Heintzenberg, J.: Saharan Mineral Dust Experiments SAMUM-1 and SAMUM-2: what have we learned?, Tellus B, 63, 403-429, https://doi.org/10.1111/j.1600-0889.2011.00555.x, 2011.

Bond, T. C., Doherty, S. J., Fahey, D. W., Forster, P. M., Berntsen, T., DeAngelo, B. J., Flanner, M. G., Ghan, S., Kärcher, B., Koch, D., Kinne, S., Kondo, Y., Quinn, P. K., Sarofim, M. C., Schultz, M. G., Schulz, M., Venkataraman, C., Zhang, H., Zhang, S., Bellouin, N., Guttikunda, S. K., Hopke, P. K., Jacobson, M. Z., Kaiser, J. W., Klimont, Z., Lohmann, U., Schwarz, J. P., Shindell, D., Storelvmo, T., Warren, S. G., and Zender, C. S.: Bounding the role of black carbon in the climate system: A scientific assessment, J. Geophys. Res., 118, 1-173, https://doi.org/10.1002/jgrd.50171, 2013.

Boucher, O., Randall, D., Artaxo, P., Bretherton, C., Feingold, G., Forster, P., Kerminen, V.-M., Kondo, Y., Liao, H., Lohmann, U., Rasch, P., Satheesh, S. K., Sherwood, S., Stevens, B., and Zhang, X. Y.: Clouds and aerosols, in: Climate Change 2013: The Physical Science Basis. Contribution of Working Group I to the Fifth Assessment Report of the Intergovernmental Panel on Climate Change, edited by: Stocker, T. F., Qin, D., Plattner, G.-K., Tignor, M., Allen, S. K., Boschung, J., Nauels, A., Xia, Y., Bex, V., and Midgley, P. M., Cambridge University Press, Cambridge, UK and New York, USA, 571-657, https://doi.org/10.1017/CBO9781107415324.016, 2013.

Capes, G., Johnson, B., McFiggans, G., Williams, P. I., Haywood, J. M., and Coe, H.: Aging of biomass burning aerosols over West Africa: Aircraft measurements of chemical composition, microphysical properties and emission ratios, J. Geophys. Res., 113, D00C15, https://doi.org/10.1029/2008JD009845, 2008.

Carrico, C. M., Prenni, A. J., Kreidenweis, S. M., Levin, E. J., McCluskey, C. S., DeMott, P. J., and McMeeking, G. R.: Rapidly evolving ultrafine and fine mode biomass smoke physical properties: comparing laboratory and field results, J. Geophys. Res.-Atmos., 121, 5750-5768, https://doi.org/10.1002/2015JD024389, 2016.

Chakrabarty, R. K., Moosmüller, H., Chen, L.-W. A., Lewis, K., Arnott, W. P., Mazzoleni, C., Dubey, M. K., Wold, C. E., Hao, W. M., and Kreidenweis, S. M.: Brown carbon in tar balls from smoldering biomass combustion, Atmos. Chem. Phys., 10, 6363 6370, https://doi.org/10.5194/acp-10-6363-2010, 2010.

Chen, G., Ziemba, L. D., Chu, D. A., Thornhill, K. L., Schuster, G. L., Winstead, E. L., Diskin, G. S., Ferrare, R. A., Burton, S. P., Ismail, S., Kooi, S. A., Omar, A. H., Slusher, D. L., Kleb, M. M., Reid, J. S., Twohy, C. H., Zhang, H., and Anderson, B. E.: Observations of Saharan dust microphysical and optical properties from the Eastern Atlantic during NAMMA airborne field campaign, Atmos. Chem. Phys., 11, 723-740, https://doi.org/10.5194/acp-11-723-2011, 2011.

Chou, C., Formenti, P., Maille, M., Ausset, P., Helas, G., Osborne, S., and Harrison, M.: Size distribution, shape and composition of dust aerosols collected during the AMMA SOP0 field campaign 
in the northeast of Niger, January 2006, J. Geophys. Res., 113, D00C10, https://doi.org/10.1029/2008JD009897, 2008.

Clarke, A., McNaughton, C., Kapustin, V., Shinozuka, Y., Howell, S., Dibb, J., Zhou, J., Anderson, B., Brekhovskikh, V., Turner, H., and Pinkerton, M.: Biomass burning and pollution aerosol over North America: organic components and their influence on spectral optical properties and humidification response, J. Geophys. Res., 112, D12S18, https://doi.org/10.1029/2006JD007777, 2007.

Colomb, A. and Piguet, B.: ATR GAS O $3, \mathrm{NO}, \mathrm{NO}_{2}, \mathrm{SO}_{2}$, available at: https://baobab.sedoo.fr/Data-Search/?datsId=1738\&project_ name=DACCIWA (last access: 20 April 2020), 2017.

Corr, C. A., Hall, S. R., Ullmann, K., Anderson, B. E., Beyersdorf, A. J., Thornhill, K. L., Cubison, M. J., Jimenez, J. L., Wisthaler, A., and Dibb, J. E.: Spectral absorption of biomass burning aerosol determined from retrieved single scattering albedo during ARCTAS, Atmos. Chem. Phys., 12, 10505-10518, https://doi.org/10.5194/acp-12-10505-2012, 2012.

Deetz, K., Vogel, H., Haslett, S., Knippertz, P., Coe, H., and Vogel, B.: Aerosol liquid water content in the moist southern West African monsoon layer and its radiative impact, Atmos. Chem. Phys., 18, 14271-14295, https://doi.org/10.5194/acp-18-142712018, 2018.

Denjean, C. and Bourrianne, T.: ATR Aerosol Extinction, available at: https://baobab.sedoo.fr/Data-Search/?datsId=1695\&project_ name=DACCIWA (last access: 20 April 2020), 2017a.

Denjean, C. and Bourrianne, T.: ATR Aerosol OPC, available at: https://baobab.sedoo.fr/Data-Search/?datsId=1708\&project_ name=DACCIWA (last access: 20 April 2020), 2017 b.

Denjean, C., Cassola, F., Mazzino, A., Triquet, S., Chevaillier, S., Grand, N., Bourrianne, T., Momboisse, G., Sellegri, K., Schwarzenbock, A., Freney, E., Mallet, M., and Formenti, P.: Size distribution and optical properties of mineral dust aerosols transported in the western Mediterranean, Atmos. Chem. Phys., 16, 1081-1104, https://doi.org/10.5194/acp16-1081-2016, 2016.

Deroubaix, A., Menut, L., Flamant, C., Brito, J., Denjean, C., Dreiling, V., Fink, A., Jambert, C., Kalthoff, N., Knippertz, P., Ladkin, R., Mailler, S., Maranan, M., Pacifico, F., Piguet, B., Siour, G., and Turquety, S.: Diurnal cycle of coastal anthropogenic pollutant transport over southern West Africa during the DACCIWA campaign, Atmos. Chem. Phys., 19, 473-497, https://doi.org/10.5194/acp-19-473-2019, 2019.

Di Biagio, C., Formenti, P., Doppler, L., Gaimoz, C., Grand, N., Ancellet, G., Attié, J.-L., Bucci, S., Dubuisson, P., Fierli, F., Mallet, M., and Ravetta, F.: Continental pollution in the Western Mediterranean basin: large variability of the aerosol single scattering albedo and influence on the direct shortwave radiative effect, Atmos. Chem. Phys., 16, 10591-10607, https://doi.org/10.5194/acp-16-10591-2016, 2016.

Dubovik, O., Holben, B. N., Eck, T. F., Smirnov, A., Kaufman, Y. J., King, M. D., Tanre, D., and Slutsker, I.: Climatology of atmospheric aerosol absorption and optical properties in key locations, J. Atmos. Sci., 59, 590-608, 2002.

Flamant, C., Deroubaix, A., Chazette, P., Brito, J., Gaetani, M., Knippertz, P., Fink, A. H., de Coetlogon, G., Menut, L., Colomb, A., Denjean, C., Meynadier, R., Rosenberg, P., Dupuy, R., Dominutti, P., Duplissy, J., Bourrianne, T., Schwarzenboeck, A., Ramonet, M., and Totems, J.: Aerosol distribution in the northern
Gulf of Guinea: local anthropogenic sources, long-range transport, and the role of coastal shallow circulations, Atmos. Chem. Phys., 18, 12363-12389, https://doi.org/10.5194/acp-18-123632018, 2018a.

Flamant, C., Knippertz, P., Fink, A. H., Akpo, A., Brooks, B., Chiu, C. J., Coe, H., Danuor, S., Evans, M., Jegede, O., Kalthoff, N., Konaré, A., Liousse, C., Lohou, F., Mari, C., Schlager, H., Schwarzenboeck, A., Adler, B., Amekudzi, L., Aryee, J., Ayoola, M., Batenburg, A. M., Bessardon, G., Borrmann, S., Brito, J., Bower, K., Burnet, F., Catoire, V., Colomb, A., Denjean, C., Fosu-Amankwah, K., Hill, P. G., Lee, J., Lothon, M., Maranan, M., Marsham, J., Meynadier, R., Ngamini, J.-B., Rosenberg, P., Sauer, D., Smith, V., Stratmann, G., Taylor, J. W., Voigt, C., and Yoboué, V.: The Dynamics-Aerosol-ChemistryCloud Interactions in West Africa field campaign: Overview and research highlights, B. Am. Meteorol. Soc., 99, 83-104, https://doi.org/10.1175/BAMS-D-16-0256.1, $2018 \mathrm{~b}$.

Formenti, P., Schütz, L., Balkanski, Y., Desboeufs, K., Ebert, M., Kandler, K., Petzold, A., Scheuvens, D., Weinbruch, S., and Zhang, D.: Recent progress in understanding physical and chemical properties of African and Asian mineral dust, Atmos. Chem. Phys., 11, 8231-8256, https://doi.org/10.5194/acp11-8231-2011, 2011a.

Formenti, P., Rajot, J. L., Desboeufs, K., Saïd, F., Grand, N., Chevaillier, S., and Schmechtig, C.: Airborne observations of mineral dust over western Africa in the summer Monsoon season: spatial and vertical variability of physico-chemical and optical properties, Atmos. Chem. Phys., 11, 6387-6410, https://doi.org/10.5194/acp-11-6387-2011, 2011 b.

Formenti, P., D’Anna, B., Flamant, C., Mallet, M., Piketh, S. J., Schepanski, K., Waquet, F., Auriol, F., Brogniez, G., Burnet, F., Chaboureau, J., Chauvigné, A., Chazette, P., Denjean, C., Desboeufs, K., Doussin, J., Elguindi, N., Feuerstein, S., Gaetani, M., Giorio, C., Klopper, D., Mallet, M. D., Nabat, P., Monod, A., Solmon, F., Namwoonde, A., Chikwililwa, C., Mushi, R., Welton, E. J., and Holben, B.: The Aerosols, Radiation and Clouds in southern Africa (AEROCLO-sA) field campaign in Namibia: overview, illustrative observations and way forward, B. Am. Meteorol. Soc., 100, 1277-1298, https://doi.org/10.1175/BAMS-D17-0278.1, 2019.

Forrister, H., Liu, J., Scheuer, E., Dibb, J., Ziemba, L., Thornhill, K. L., Anderson, B., Diskin, G., Perring, A. E., and Schwarz, J. P.: Evolution of brown carbon in wildfire plumes, Geophys. Res. Lett., 42, 4623-4630, 2015.

Haslett, S. L., Taylor, J. W., Evans, M., Morris, E., Vogel, B., Dajuma, A., Brito, J., Batenburg, A. M., Borrmann, S., Schneider, J., Schulz, C., Denjean, C., Bourrianne, T., Knippertz, P., Dupuy, R., Schwarzenböck, A., Sauer, D., Flamant, C., Dorsey, J., Crawford, I., and Coe, H.: Remote biomass burning dominates southern West African air pollution during the monsoon, Atmos. Chem. Phys., 19, 15217-15234, https://doi.org/10.5194/acp-1915217-2019, 2019.

Haywood, J. M., Francis, P., Osborne, S., Glew, M., Loeb, N., Highwood, E., Tanre, D., Myhre, G., Formenti, P., and Hirst, E.: Radiative properties and direct radiative effect of Saharan dust measured by the C-130 aircraft during SHADE:1. Solar spectrum, J. Geophys. Res.-Atmos., 108, 8577, https://doi.org/10.1029/2002jd002687, 2003a. 
Haywood, J. M., Osborne, S. R., Francis, P. N., Keil, A., Formenti, P., Andreae, M. O., and Kaye, P. H.: The mean physical and optical properties of regional haze dominated by biomass burning aerosol measured from the C-130 aircraft during SAFARI 2000, J. Geophys. Res., 108, 8473, https://doi.org/10.1029/2002JD002226, 2003b.

Haywood, J. M., Pelon, J., Formenti, P., Bharmal, N., Brooks, M., Capes, G., Chazette, P., Chou, C., Christopher, S., Coe, H., Cuesta, J., Derimian, Y., Desboeufs, K., Greed, G., Harrison, M., Heese, B., Highwood, E. J., Johnson, B., Mallet, M., Marticorena, B., Marsham, J., Milton, S., Myhre, G., Osborne, S. R., Parker, D. J., Rajot, J.-L., Schulz, M., Slingo, A., Tanre, D., and Tulet, P.: Overview of the dust and biomass-burning experiment and African Monsoon multidisciplinary analysis special observing period-0, J. Geophys. Res., 113, D00C17, https://doi.org/10.1029/2008JD010077, 2008.

Heintzenberg, J.: The SAMUM-1 experiment over Southern Morocco: Overview and introduction, Tellus B, 61, 2-11, 2009.

Hess, M., Koepke, P., and Schult I.: Optical properties of aerosols and clouds, B. Am. Meteorol. Soc., 79, 831-844, 1998.

Janhäll, S., Andreae, M. O., and Pöschl, U.: Biomass burning aerosol emissions from vegetation fires: particle number and mass emission factors and size distributions, Atmos. Chem. Phys., 10, 1427-1439, https://doi.org/10.5194/acp-101427-2010, 2010.

Johnson, B. T., Heese, B., McFarlane, S. A., Chazette, P., Jones, A., and Bellouin, N.: Vertical distribution and radiative effects of mineral dust and biomass burning aerosol over West Africa during DABEX, J. Geophys. Res., 113, D00C12, https://doi.org/10.1029/2008JD009848, 2008.

Jolly, W. M., Cochrane, M. A., Freeborn, P. H., Holden, Z. A., Brown, T. J., Williamson, G. J., and Bowman, D. M. J. S.: Climate-induced variations in global wildfire danger from 1979 to 2013, Nat. Commun., 6, 7537, https://doi.org/10.1038/ncomms8537, 2015.

Kalthoff, N., Lohou, F., Brooks, B., Jegede, G., Adler, B., Babić, K., Dione, C., Ajao, A., Amekudzi, L. K., Aryee, J. N. A., Ayoola, M., Bessardon, G., Danuor, S. K., Handwerker, J., Kohler, M., Lothon, M., Pedruzo-Bagazgoitia, X., Smith, V., Sunmonu, L., Wieser, A., Fink, A. H., and Knippertz, P.: An overview of the diurnal cycle of the atmospheric boundary layer during the West African monsoon season: results from the 2016 observational campaign, Atmos. Chem. Phys., 18, 2913-2928, https://doi.org/10.5194/acp-18-2913-2018, 2018.

Kirchstetter, T. W., Novakov, T., and Hobbs, P.: Evidence that the spectral dependence of light absorption by aerosols is affected by organic carbon, J. Geophys. Res., 109, D21208, https://doi.org/10.1029/2004JD004999, 2004.

Knippertz, P., Evans, M. J., Field, P. R., Fink, A. H., Liousse, C., and Marsham, J. H.: The possible role of local air pollution in climate change in West Africa, Nat. Clim. Change, 5, 815-822, https://doi.org/10.1038/nclimate2727, 2015a.

Knippertz, P., Coe, H., Chiu, J. C., Evans, M. J., Fink, A. H., Kalthoff, N., Liousse, C., Mari, C., Allan, R. P., Brooks, B., Danour, S., Flamant, C., Jegede, O. O., Lohou, F., and Marsham, J. H.: The dacciwa project: Dynamics-Aerosol- Chemistry-Cloud Interactions in West Africa, B. Am. Meteorol. Soc., 96, 14511460, https://doi.org/10.1175/BAMS-D-14-00108.1, 2015b.
Knippertz, P., Fink, A. H., Deroubaix, A., Morris, E., Tocquer, F., Evans, M. J., Flamant, C., Gaetani, M., Lavaysse, C., Mari, C., Marsham, J. H., Meynadier, R., Affo-Dogo, A., Bahaga, T., Brosse, F., Deetz, K., Guebsi, R., Latifou, I., Maranan, M., Rosenberg, P. D., and Schlueter, A.: A meteorological and chemical overview of the DACCIWA field campaign in West Africa in June-July 2016, Atmos. Chem. Phys., 17, 10893-10918, https://doi.org/10.5194/acp-17-10893-2017, 2017.

Lack, D. A., Langridge, J. M., Bahreini, R., Cappa, C. D., Middlebrook, A. M., and Schwarz J. P.: Brown carbon and internal mixing in biomass burning particles, P. Natl. Acad. Sci. USA, 109, 14802-14807, https://doi.org/10.1073/pnas.1206575109, 2012.

Laing, J. R., Jaffe, D. A., and Hee, J. R.: Physical and optical properties of aged biomass burning aerosol from wildfires in Siberia and the Western USA at the Mt. Bachelor Observatory, Atmos. Chem. Phys., 16, 15185-15197, https://doi.org/10.5194/acp-1615185-2016, 2016.

Lebel, T., Parker, D. J., Flamant, C., Bourles, B., Marticorena, M., Mougin, E., Peugeot, C., Diedhiou, A., Haywood, J. M., Ngamini, J. B., Polcher, J., Redelsperger, J. L., and Thorncroft, C. D.: The AMMA field campaigns: multiscale and multidisciplinary observations in the West African region, Q. J. Roy. Meteor. Soc., 136, 8-33, 2010.

Lewis, K., Arnott, W. P., Moosmuller, H., and Wold, C. E.: Strong spectral variation of biomass smoke light absorption and single scattering albedo observed with a novel dual-wavelength photoacoustic instrument, J. Geophys. Res., 113, D16203, https://doi.org/10.1029/2007jd009699, 2008.

Lieke, K., Kandler, K., Scheuvens, D., Emmel, C., Von Glahn, C., Petzold, A., Weinzierl, B., Veira, A., Ebert, M., Weinbruch, S., and SchÜTz, L.: Particle chemical properties in the vertical column based on aircraft observations in the vicinity of Cape Verde Islands, Tellus B, 63, 497-511, https://doi.org/10.1111/j.16000889.2011.00553.x, 2011.

Liousse, C., Assamoi, E., Criqui, P., Granier, C., and Rosset, R.: Explosive growth in African combustion emissions from 2005 to 2030, Environ. Res. Lett., 9, 035003, https://doi.org/10.1088/1748-9326/9/3/035003, 2014.

Liu, D., Taylor, J. W., Crosier, J., Marsden, N., Bower, K. N., Lloyd, G., Ryder, C. L., Brooke, J. K., Cotton, R., Marenco, F., Blyth, A., Cui, Z., Estelles, V., Gallagher, M., Coe, H., and Choularton, T. W.: Aircraft and ground measurements of dust aerosols over the west African coast in summer 2015 during ICE-D and AER-D, Atmos. Chem. Phys., 18, 3817-3838, https://doi.org/10.5194/acp-18-3817-2018, 2018.

Magi, B. I., Magi, A., Hobbs, P. V., Schmid, B., and Redemann, J.: Vertical profiles of light scattering, light absorption and singlescattering albedo during the dry, biomass burning season in southern Africa and comparisons of in situ and remote sensing measurements of aerosol optical depths, J. Geophys. Res., 108, 8504, https://doi.org/10.1029/2002JD002361, 2003.

Mallet, M., Nabat, P., Zuidema, P., Redemann, J., Sayer, A. M., Stengel, M., Schmidt, S., Cochrane, S., Burton, S., Ferrare, R., Meyer, K., Saide, P., Jethva, H., Torres, O., Wood, R., Saint Martin, D., Roehrig, R., Hsu, C., and Formenti, P.: Simulation of the transport, vertical distribution, optical properties and radiative impact of smoke aerosols with the ALADIN regional climate model during the ORACLES-2016 and LASIC experiments, At- 
mos. Chem. Phys., 19, 4963-4990, https://doi.org/10.5194/acp19-4963-2019, 2019.

Mann, G. W., Carslaw, K. S., Reddington, C. L., Pringle, K. J., Schulz, M., Asmi, A., Spracklen, D. V., Ridley, D. A., Woodhouse, M. T., Lee, L. A., Zhang, K., Ghan, S. J., Easter, R. C., Liu, X., Stier, P., Lee, Y. H., Adams, P. J., Tost, H., Lelieveld, J., Bauer, S. E., Tsigaridis, K., van Noije, T. P. C., Strunk, A., Vignati, E., Bellouin, N., Dalvi, M., Johnson, C. E., Bergman, T., Kokkola, H., von Salzen, K., Yu, F., Luo, G., Petzold, A., Heintzenberg, J., Clarke, A., Ogren, J. A., Gras, J., Baltensperger, U., Kaminski, U., Jennings, S. G., O’Dowd, C. D., Harrison, R. M., Beddows, D. C. S., Kulmala, M., Viisanen, Y., Ulevicius, V., Mihalopoulos, N., Zdimal, V., Fiebig, M., Hansson, H.-C., Swietlicki, E., and Henzing, J. S.: Intercomparison and evaluation of global aerosol microphysical properties among AeroCom models of a range of complexity, Atmos. Chem. Phys., 14, 4679-4713, https://doi.org/10.5194/acp-14-4679-2014, 2014.

Mari, C. H., Cailley, G., Corre, L., Saunois, M., Attié, J. L., Thouret, V., and Stohl, A.: Tracing biomass burning plumes from the Southern Hemisphere during the AMMA 2006 wet season experiment, Atmos. Chem. Phys., 8, 3951-3961, https://doi.org/10.5194/acp-8-3951-2008, 2008.

Martinorena, B. and Bergametti, G.: Two-year simulations of seasonal and interannual changes of the Saharan dust emissions, Geophys. Res. Lett., 23, 1921-1924, 1996.

Massoli, P., Kebabian, P. L., Onasch, T. B., Hills, F. B., and Freedman, A.: Aerosol light extinction measurements by Cavity Attenuated Phase Shift (CAPS) Spectroscopy: Laboratory validation and field deployment of a compact aerosol particle extinction monitor, Aerosol Sci. Tech., 44, 428-435, https://doi.org/10.1080/02786821003716599, 2010.

McConnell, C. L., Highwood, E. J., Coe, H., Formenti, P., Anderson, B., Osborne, S., Nava, S., Desboeufs, K., Chen, G., and Harrison, M. A. J.: Seasonal variations of the physical and optical characteristics of Saharan dust: Results from the Dust Outflowand Deposition to the Ocean (DODO) experiment, J. Geophys. Res., 113, D14S05, https://doi.org/10.1029/2007JD009606, 2008.

Menut, L., Flamant, C., Turquety, S., Deroubaix, A., Chazette, P., and Meynadier, R.: Impact of biomass burning on pollutant surface concentrations in megacities of the Gulf of Guinea, Atmos. Chem. Phys., 18, 2687-2707, https://doi.org/10.5194/acp18-2687-2018, 2018.

Mertes, S., Schröder, F., and Wiedensohler, A.: The particle detection efficiency curve of the TSI $3010 \mathrm{CPC}$ as a function of the temperature difference between saturator and condenser, Aerosol Sci. Tech., 23, 257-261, 1995.

Mita, A. and Isono, K.: Effective complex refractive index of atmospheric aerosols containing absorbing substances, J. Meteorol. Soc. Jpn., 58, 69-80, https://doi.org/10.2151/jmsj1965.58.1_69, 1980.

Myhre, G., Samset, B. H., Schulz, M., Balkanski, Y., Bauer, S., Berntsen, T. K., Bian, H., Bellouin, N., Chin, M., Diehl, T., Easter, R. C., Feichter, J., Ghan, S. J., Hauglustaine, D., Iversen, T., Kinne, S., Kirkevåg, A., Lamarque, J.-F., Lin, G., Liu, X., Lund, M. T., Luo, G., Ma, X., van Noije, T., Penner, J. E., Rasch, P. J., Ruiz, A., Seland, Ø., Skeie, R. B., Stier, P., Takemura, T., Tsigaridis, K., Wang, P., Wang, Z., Xu, L., Yu, H., Yu, F., Yoon, J.-H., Zhang, K., Zhang, H., and Zhou, C.: Radiative forcing of the direct aerosol effect from AeroCom Phase II simulations, Atmos. Chem. Phys., 13, 1853-1877, https://doi.org/10.5194/acp13-1853-2013, 2013.

Petzold, A., Rasp, K., Weinzierl, B., Esselborn, M., Hamburger, T., Dornbrack, A., Kandler, K., Schutz, L., Knippertz, P., Fiebig, M., and Virkkula, A.: Saharan dust refractive index and optical properties from aircract-based observations during SAMUM 2006, Tellus B, 61, 118-130, 2009.

Petzold, A., Veira, A., Mund, S., Esselborn, M., Kiemle, C., Weinzierl, B., Hamburger, T., Ehret, G., Lieke, K., and Kandler, K.: Mixing of mineral dust with urban pollution aerosol over Dakar (Senegal): impact on dust physicochemical and radiative properties, Tellus B, 63, 619-634, https://doi.org/10.1111/j.1600-0889.2011.00547.x, 2011.

Petzold, A., Onasch, T., Kebabian, P., and Freedman, A.: Intercomparison of a Cavity Attenuated Phase Shift-based extinction monitor (CAPS PMex) with an integrating nephelometer and a filterbased absorption monitor, Atmos. Meas. Tech., 6, 1141-1151, https://doi.org/10.5194/amt-6-1141-2013, 2013.

Pistone, K., Redemann, J., Doherty, S., Zuidema, P., Burton, S., Cairns, B., Cochrane, S., Ferrare, R., Flynn, C., Freitag, S., Howell, S. G., Kacenelenbogen, M., LeBlanc, S., Liu, X., Schmidt, K. S., Sedlacek III, A. J., Segal-Rozenhaimer, M., Shinozuka, Y., Stamnes, S., van Diedenhoven, B., Van Harten, G., and Xu, F.: Intercomparison of biomass burning aerosol optical properties from in situ and remote-sensing instruments in ORACLES-2016, Atmos. Chem. Phys., 19, 9181-9208, https://doi.org/10.5194/acp-19-9181-2019, 2019.

Pokhrel, R. P., Wagner, N. L., Langridge, J. M., Lack, D. A., Jayarathne, T., Stone, E. A., Stockwell, C. E., Yokelson, R. J., and Murphy, S. M.: Parameterization of single-scattering albedo (SSA) and absorption Ångström exponent (AAE) with EC / OC for aerosol emissions from biomass burning, Atmos. Chem. Phys., 16, 9549-9561, https://doi.org/10.5194/acp-169549-2016, 2016.

Ramonet, M., Piquet, B., and Hazan, L.: ATR GAS $\mathrm{CO}_{2}, \mathrm{CH}_{4}$, CO, available at: https://baobab.sedoo.fr/Data-Search/?datsId= 1745\&project_name=DACCIWA (last access: 20 April 2020), 2017.

Reid, J. S., Eck, T. F., Christopher, S. A., Koppmann, R., Dubovik, O., Eleuterio, D. P., Holben, B. N., Reid, E. A., and Zhang, J.: A review of biomass burning emissions part III: intensive optical properties of biomass burning particles, Atmos. Chem. Phys., 5, 827-849, https://doi.org/10.5194/acp-5-827-2005, 2005.

Roehrig, R., Bouniol, D., Guichard, F., Hourdin, F. D., and Redelsperger, J. L.: The present and future of the west african monsoon: A process-oriented assessment of CMIP5 simulations along the AMMA transect, J. Climate, 26, 6471-6505, https://doi.org/10.1175/JCLI-D-12-00505.1, 2013.

Romonosky, D., Gomez, S., Lam, J., Carrico, C., Aiken, A., Chylek, P., and Dubey, M.: Optical Properties of Laboratory \& Ambient Biomass Burning Aerosols: Elucidating Black, Brown, \& Organic Carbon Components \& Mixing Regimes, J. Geophys. Res.-Atmos., 124, 5088-5105, https://doi.org/10.1029/2018JD029892, 2019.

Russell, M., Zhang, S.-H., Flagan, R. C., Seinfeld, J. H., Stolzenburg, M. R., and Caldow, R.: Radially classified aerosol detector for aircraft-based submicron aerosol measurements, J. Atmos. Ocean. Tech., 13, 598-609, 1996. 
Ryder, C. L., Highwood, E. J., Rosenberg, P. D., Trembath, J., Brooke, J. K., Bart, M., Dean, A., Crosier, J., Dorsey, J., Brindley, H., Banks, J., Marsham, J. H., McQuaid, J. B., Sodemann, H., and Washington, R.: Optical properties of Saharan dust aerosol and contribution from the coarse mode as measured during the Fennec 2011 aircraft campaign, Atmos. Chem. Phys., 13, 303325, https://doi.org/10.5194/acp-13-303-2013, 2013.

Ryder, C. L., Marenco, F., Brooke, J. K., Estelles, V., Cotton, R., Formenti, P., McQuaid, J. B., Price, H. C., Liu, D., Ausset, P., Rosenberg, P. D., Taylor, J. W., Choularton, T., Bower, K., Coe, H., Gallagher, M., Crosier, J., Lloyd, G., Highwood, E. J., and Murray, B. J.: Coarse-mode mineral dust size distributions, composition and optical properties from AER-D aircraft measurements over the tropical eastern Atlantic, Atmos. Chem. Phys., 18, 17225-17257, https://doi.org/10.5194/acp-18-172252018, 2018.

Sakamoto, K. M., Allan, J. D., Coe, H., Taylor, J. W., Duck, T. J., and Pierce, J. R.: Aged boreal biomass-burning aerosol size distributions from BORTAS 2011, Atmos. Chem. Phys., 15, 16331646, https://doi.org/10.5194/acp-15-1633-2015, 2015.

Sakamoto, K. M., Laing, J. R., Stevens, R. G., Jaffe, D. A., and Pierce, J. R.: The evolution of biomass-burning aerosol size distributions due to coagulation: dependence on fire and meteorological details and parameterization, Atmos. Chem. Phys., 16, 7709-7724, https://doi.org/10.5194/acp-16-7709-2016, 2016.

Sandradewi, J., Prevot, A. S. H., Weingartner, E., Schmidhauser, R., Gysel, M., and Baltensperger, U.: A study of wood burning and traffic aerosols in an Alpine valley using a multi-wavelength Aethalometer, Atmos. Environ., 42, 101-112, https://doi.org/10.1016/j.atmosenv.2007.09.034, 2008.

Schladitz, A., Muller, T., Kaaden, N., Massling, A., Kandler, K., Ebert, M., Weinbruch, S., Deutscher, C., and Wiedensohler, A.: In situ measurements of optical properties at Tinfou (Morocco) during the Saharan Mineral Dust Experiment SAMUM 2006, Tellus B, 61, 64-78, https://doi.org/10.1111/j.16000889.2008.00397.x, 2009.

Schuster, G. L., Dubovik, O., and Holben, B. N.:Angstrom exponent and bimodal aerosol size distributions, J. Geophys. Res., 111, D07207, https://doi.org/10.1029/2005JD006328, 2006.

Schwarz, J. P., Spackman, J. R., Fahey, D. W., Gao, R. S., Lohmann, U., Stier, P., Watts, L. A., Thomson, D. S., Lack, D. A., Pfister, L., Mahoney, M. J., Baumgardner, D., Wilson, J. C., and Reeves, J. M.: Coatings and their enhancement of black carbon light absorption in the tropical atmosphere, J. Geophys. Res., 113, D03203, https://doi.org/10.1029/2007JD009042, 2008.

Schwarzenboeck, A. and Dupuy, R.: ATR Aerosol Absorption, available at: https://baobab.sedoo.fr/Data-Search/?datsId= 1716\&project_name=DACCIWA (last access: 20 April 2020), $2017 \mathrm{a}$.

Schwarzenboeck, A. and Dupuy, R.: ATR Aerosol CPC, available at: https://baobab.sedoo.fr/Data-Search/?datsId=1713\&project_ name=DACCIWA (last access: 20 April 2020), $2017 \mathrm{~b}$.

Schwarzenboeck, A. and Dupuy, R.: ATR Aerosol Diffusion, available at: https://baobab.sedoo.fr/Data-Search/?datsId= 1715\&project_name=DACCIWA (last access: 20 April 2020), 2017c.

Seinfeld, J. H. and Pandis, S. N.: Properties of the Atmospheric Aerosol, in: Atmospheric Chemistry and Physics: From Air Pol- lution to Climate Change, 2nd ed., John Wiley \& Sons, New Jersey, USA, 350-388, 2006.

Shin, S.-K., Tesche, M., Noh, Y., and Müller, D.: Aerosol-type classification based on AERONET version 3 inversion products, Atmos. Meas. Tech., 12, 3789-3803, https://doi.org/10.5194/amt12-3789-2019, 2019.

Silva, S. and Arellano, A.: Characterizing regional-scale combustion using satellite retrievals of $\mathrm{CO}, \mathrm{NO}_{2}$ and $\mathrm{CO}_{2}$, Remote Sens., 9, 744, https://doi.org/10.3390/rs9070744, 2017.

Solmon, F., Mallet, M., Elguindi, N., Giorgi, F., Zakey, A., and Konare, A.: Dust aerosol impact on regional precipitation over western Africa, mechanisms and sensitivity to absorption properties, Geophys. Res. Lett., 35, L24705, https://doi.org/10.1029/2008GL035900, 2008.

Stier, P., Schutgens, N. A. J., Bellouin, N., Bian, H., Boucher, O., Chin, M., Ghan, S., Huneeus, N., Kinne, S., Lin, G., Ma, X., Myhre, G., Penner, J. E., Randles, C. A., Samset, B., Schulz, M., Takemura, T., Yu, F., Yu, H., and Zhou, C.: Host model uncertainties in aerosol radiative forcing estimates: results from the AeroCom Prescribed intercomparison study, Atmos. Chem. Phys., 13, 3245-3270, https://doi.org/10.5194/acp-13-3245-2013, 2013.

Stohl, A., Eckhardt, S., Forster, C., James, P., Spichtinger, N., and Seibert, P.: A replacement for simple back trajectory calculations in the interpretation of atmospheric trace substance measurements, Atmos. Environ., 36, 4635-4648, 2002.

Vakkari, V., Kerminen, V. M., Beukes, J. P., Tiitta, P., van Zyl, P. G., Josipovic, M., Venter, A. D., Jaars, K.,Worsnop, D. R., Kulmala, M., and Laakso, L.: Rapid changes in biomass burning aerosols by atmospheric oxidation, Geophys. Res. Lett., 41, 2644-2651, https://doi.org/10.1002/2014gl059396, 2014.

Virkkula, A.: Correction of the Calibration of the 3-wavelength Particle Soot Absorption Photometer (3 $\lambda$ PSAP), Aerosol Sci. Tech., 44, 706-712, https://doi.org/10.1080/02786826.2010.482110, 2010.

Wang, T., Cheung, T. F., Li, Y. S., Yu, X. M., and Blake, D. R.: Emission characteristics of $\mathrm{CO}, \mathrm{NO}_{x}, \mathrm{SO}_{2}$ and indications of biomass burning observed at a rural site in eastern China, J. Geophys. Res., 107, 4157, https://doi.org/10.1029/2001JD000724, 2002.

Weinzierl, B., Sauer, D., Esselborn, M., Petzold, A., Veira, A., Rose, M., Mund, S., Wirth, M., Ansmann, A., Tesche, M., Gross, S., and Freudenthaler, V.: Microphysical and optical properties of dust and tropical biomass burning aerosol layers in the Cape Verde region - an overview of the airborne in situ and lidar measurements during SAMUM-2, Tellus B, 63, 589-618, https://doi.org/10.1111/j.1600-0889.2011.00566.x, 2011.

Wiedensohler, A., Orsini, D., Covert, D. S., Coffmann, D., Cantrell, W., Havlicek, M., Brechtel, F. J., Russell, L. M., Weber, R. J., Gras, J., Hudson, J. G., and Litchy M.: Intercomparison study of size-dependent counting efficiency of 26 condensation particle counters, Aerosol Sci. Tech., 27, 224-242, 1997.

Yokelson, R. J., Crounse, J. D., DeCarlo, P. F., Karl, T., Urbanski, S., Atlas, E., Campos, T., Shinozuka, Y., Kapustin, V., Clarke, A. D., Weinheimer, A., Knapp, D. J., Montzka, D. D., Holloway, J., Weibring, P., Flocke, F., Zheng, W., Toohey, D., Wennberg, P. O., Wiedinmyer, C., Mauldin, L., Fried, A., Richter, D., Walega, J., Jimenez, J. L., Adachi, K., Buseck, P. R., Hall, S. R., and Shetter, R.: Emissions from biomass burning in the Yucatan, Atmos 
Chem. Phys., 9, 5785-5812, https://doi.org/10.5194/acp-9-57852009, 2009.

Zhong, M. and Jang, M.: Dynamic light absorption of biomass-burning organic carbon photochemically aged under natural sunlight, Atmos. Chem. Phys., 14, 1517-1525, https://doi.org/10.5194/acp-14-1517-2014, 2014.

Zuidema, P., Redeman, J., Haywood, J., Wood, R., Piketh, S., Hipondoka, M., and Formenti, P.: Smoke and clouds above the southeast Atlantic: upcoming field campaigns probe absorbing aerosols impact on climate, B. Am. Meteorol. Soc., 97, 11311135, https://doi.org/10.1175/BAMS-D-15-00082.1, 2016.
Zuidema, P., Sedlacek III, A. J., Flynn, C., Springston, S., Delgadillo, R., Zhang, J., Aiken, A. C., Koontz, A., Muradyan, P., and Zuidema, P.: The Ascension Island boundary layer in the remote southeast Atlantic is often smoky, Geophys. Res. Lett., 45, 4456-4465, https://doi.org/10.1002/2017GL076926, 2018. 